\title{
Article title: Developing a Level of Service (LOS) Index for Operational Management of Public Buildings
}

\section{Authors and affiliations:}

Rajeev Ruparathna ${ }^{1}$, Kasun Hewage ${ }^{2}$, Rehan Sadiq ${ }^{3}$

${ }^{1,2,3}$ School of Engineering, University of British Columbia (Okanagan Campus), 1137 Alumni Avenue, Kelowna, BC V1V 1V7, Canada

Email:

${ }^{1}$ rajeev.ruparathna@ubc.ca

${ }^{2}$ kasun.hewage@ubc.ca

3 rehan.sadiq@ubc.ca

\section{Corresponding Author:}

Dr. Kasun Hewage

Associate Professor

Project \& Construction Management

School of Engineering

The University of British Columbia | Okanagan Campus

EME4227 - 1137 Alumni Avenue

Kelowna, BC, V1V 1V7, Canada.

Phone: 1.250 .807 .8176

Fax: 1.250.807.9850

Email: Kasun.Hewage@ubc.ca 


\begin{abstract}
Even though there is a large body of knowledge related to buildings, only a limited number of examples with a focus on asset management exist in published literature. More importantly, current literature lacks rating systems that support tactical and operational management of building infrastructure. This paper addresses the aforementioned knowledge gap and building industry requirement by proposing an index for operational management of a public building using building level of service (LOS). In the context of buildings, LOS is defined as an assessment of the operational performance provided to building users, society, and the environment. A fuzzy synthetic evaluation (FSE)-based method was used to assess the LOS of buildings. First, key performance categories and indicators were defined for operating building performance assessment. Indicators and benchmarks were customized for an aquatic centre building. A case study was conducted to demonstrate the application of the LOS index. Results from this approach provides an assessment of the operational performance of the aquatic centre building with respect to nine LOS performance categories. Overall building LOS was evaluated as good for the three pseudo scenarios considered. The proposed LOS index facilitates asset management of public buildings by providing information for operational, tactical, and strategic decision making.
\end{abstract}

Key Words: Public buildings, Level of Service, Fuzzy synthetic evaluation, Performance assessment 


\section{Abbreviations}

FSE Fuzzy synthetic evaluation

BPI Building performance indicators

CPI Component performance indicators

DGNB Deutsche Gesellschaft für Nachhaltiges Bauen

FPE Facility performance evaluation

GJ Gigajoule

GHG Greenhouse gas

HVAC Heating, ventilation and air conditioning

IAQ Indoor air quality

LEED Leadership in Energy and Environmental Design

LOS Level of service

LCA Life cycle analysis

PFN Pentadruple fuzzy number

PC Performance category

PI Performance indicators

POE Post-occupancy evaluation

SPI System performance indicators

USEPA The United States Environmental Protection Agency

TBP Total building performance

TQA Total quality assessment

TFN Triangular fuzzy numbers 


\section{Introduction}

\subsection{Background}

There are over 28000 federally owned buildings and a large number of provincial and municipal buildings operating in Canada. These buildings account for $15 \%$ of the Canadian infrastructure portfolio (Mirza, 2007; Environment Canada, 2013). Currently, Canada's public building infrastructure is aging and has deteriorated considerably. Consequently, public buildings have become one of the main contributors of greenhouse gases (GHG) and smog emissions in Canada (Federation of Canadian Municipalities, 2011; Lin \& Young, 2009; J. Zhao, Xin, \& Tong, 2012). The Government of British Columbia, (2013b) has indicated that buildings account for over $75 \%$ of the corporate GHG emissions generated by public sector institutions. Climate action reports of small and medium-sized municipalities reveal that buildings account for the major portion of corporate energy and GHG footprints (City of Edmonton, 2012; City of Saskatoon, 2009; City of Windsor, 2014; Hyla Environmental Services Ltd., 2011). There is an urgent need to focus on the maintenance and renovations of existing buildings to improve their energy performance, in order to comply with the climate action targets (Hall, 2014; Industry Canada, 2013).

Several researchers have highlighted the importance of focusing on the operational stage of a building due to its high environmental impact (Rincón et al., 2013). Lack of evaluation of a building's performance during the operational stage and the complexity of scoring systems are some of the major issues associated with building performance assessment (Namini, Preece, Tahmasebi, \& Shakouri, 2014). Moreover, no further evaluation is carried out after the initial building rating. Performance management is an inherent part of asset management, determining objectives, measuring progress against predefined objectives, and using findings to improve a municipality's delivery of services to the community. Currently, there is a disconnect between the 
operational knowledge and decision-making process associated with municipal infrastructure management (Federation of Canadian Municipalities, 2003). Therefore, innovative approaches are required for performance improvement of public buildings through asset management. Continuous improvement in the reduction of GHG emissions is important in order to comply with newly emerging standards (Ng, Chen, \& Wong James M.W., 2013).

Evaluating the performance of a facility is important for attaining strategic goals of an organization (Lavy, Garcia, Scinto, \& Dixit, 2014a). In common building rating systems there is a trade-off between the complexity and the quality of results (Shohet, 2003). Proactive building asset management requires accurate and up-to-date information (Grussing, 2013). Hence, performance evaluation is an important step in building management (Shohet, 2003). There are many building rating systems found in modern literature. However, implementing these rating systems is somewhat subjective, and receiving certain accreditations does not always guarantee superior building performance. Most of these rating systems are not ideal for practical implementation. Hence, they become redundant primarily due to practical inflexibility.

Asset management can facilitate the maintenance of a desired level of service (LOS), while minimizing life cycle costs and prolonging service life (United States Environmental Protection Agency (USEPA), 2012). The systematic use of "asset management" strategies can be very helpful in improving and maintaining building infrastructure, while maintaining a certain level of environmental and service targets (Grussing, 2013). Benefits of asset management include enhanced asset performance, improved risk management, and a lowered cost of ownership (Grussing, 2013). Shoolestani et al. (2014) identified building asset management as a strategic approach that can optimize life cycle costs while controlling risk, asset operational performance, and user satisfaction (Shoolestani, Shoolestani, Froese, \& Vanier, 2015a) . Ruparathna et al. (2016) 
identified asset management as an approach in maintaining the energy performance of operating buildings (Ruparathna, Hewage, \& Sadiq, 2016). In published literature, it is evident that the use of asset management for buildings has not been adequately researched and that it has been applied in a limited fashion. Since energy consuming equipment are key components of the overall building system, a systematic asset management framework has the ability to enhance the durability of a building, while maintaining the target LOS and environmental performance.

\subsection{Problem statement}

Støre-Valen \& Lohne (2016) highlighted that public buildings particularly need comprehensive operational performance assessment methods since they operate as service centres funded by tax money. Engineers' expert knowledge is focused mainly on the technical aspects and does not account for the service provided by the building (Han et al., 2015). Evaluation of LOS is a central tenant of asset management incorporates qualitative aspects into the infrastructure decision making process (Han et al., 2015). LOS indicates the ability of infrastructure to support environmental, social, and economic functions for a community, region, or an entire nation (Chasey, Garza, \& Drew, 1997). Advanced asset management methods require LOS to be defined using measurable gauges that can be monitored through established performance indicators (Asset Management BC, 2011). LOS has been used in the infrastructure management of core municipal infrastructure classes (e.g., water supply systems (Han et al., 2015), transportation infrastructure (Asadi-Shekari, Moeinaddini, \& Shah, 2012; Sharma, Al-Hussein, Safouhi, \& Bouferguène, 2008; L. Zhao, Bian, Rong, Liu, \& Shu, 2016) etc.) to assess the service delivery. The same concept can be adopted in municipal buildings to monitor and manage the operational performance. A comprehensive literature review revealed that LOS assessment of public building has been overlooked. 
The objective this paper is to develop a LOS index for building performance management. The proposed index is a self-assessment tool that monitors operational performance of buildings to ensure that buildings conform to pre-defined desired service standards. A comprehensive LOS assessment approach was developed for buildings. This approach adopts fuzzy synthetic evaluation (FSE) to account for operational data and benchmark uncertainty. LOS performance indicators (PI) were identified from literature. The proposed index was customized for an aquatic centre building. A case study was performed to demonstrate the tool with actual data from Okanagan, BC, Canada, for different institutional priorities. The proposed LOS index aims to bridge the gap between the practicality and scientific rigour of a rating system. The proposed approach would assist all three layers of infrastructure management decision makers in municipalities (i.e. strategic, tactical and operational) in planning, budget and standard setting, and operational monitoring.

\section{Literature Review}

\subsection{Building Performance Assessment}

Although most buildings do not perform as planned, completing performance assessments in the operational stage has been a challenge in the building industry. The various performance evaluation approaches for buildings include benchmarking, post-occupancy evaluation (POE), balanced scorecard, critical success factors, and key performance indicators (Lai \& Man, 2017; Lavy, Garcia, Scinto, \& Dixit, 2014b; Støre-Valen \& Lohne, 2016). POE has been used to obtain feedback on building performance (BRE Global, 2015; Lawrence \& Keime, 2016; Leaman \& Bordass, 2001). Facility performance evaluation (FPE) was introduced as an upgrade to the POE, where FPE evaluates building performance based on various categories such as aesthetics, accessibility, functionality, cost-effectiveness, productivity, safety and security, as well as 
sustainability (Zimring, 2014). Total building performance (TBP) is a diagnostic approach that incorporates six features, spatial, acoustic, visual, thermal, indoor air quality (IAQ) and building integrity (Hartkopf \& Loftness, 1999; Oyedele, Tham, Fadeyi, \& Jaiyeoba, 2012; Wong \& Jan, 2003). This approach incorporates both subjective and objective measures to evaluate a building. TBP has been used to assess the holistic performance of commercial buildings (Oyedele et al., 2012; Wong \& Jan, 2003) and performance related to individual mandates (e.g., acoustic) (Mahbub, Kua, \& Lee, 2010).

There are a large number of building rating systems, indices, and tools that are currently in use (El shenawy \& Zmeureanu, 2013). Berardi (2012) identified three different building rating systems, cumulative energy demand (CED) systems (focus on energy consumption), life cycle analysis (LCA) systems (focus on environmental aspects), and total quality assessment (TQA) systems (Berardi, 2012). The aforementioned evaluation methods used in rating systems are classified into three classes, namely calculation-based, measurement-based and hybrid methods (Wang, Yan, \& Xiao, 2012). The majority of the commonly used building rating systems are credit-based systems, e.g. BREEM ${ }^{1}$, LEED, etc. (Mistry, 2007). Namini et al. (2014) developed an indicator-based system for sustainability assessments of buildings. Vučićević et al. (2013) developed an indicatorbased sustainability rating system for residential buildings in Serbia (Vučićević, Jovanović, Afgan, \& Turanjanin, 2014). This indicator-based rating system primarily consisted of indicators related to building energy consumption. El Shenawy and Zmeureanu (2013) developed an exergy-based building rating system. This index calculates and aggregates different sustainability indicators into a single unit (Exergy) (El shenawy \& Zmeureanu, 2013).

\footnotetext{
${ }^{1}$ BREEM is the environmental rating system developed by Building Research Establishment, UK.
} 
Various drawbacks of building rating systems have been highlighted in the literature. A major criticism for building rating systems is related to the length of time spent on project evaluation (Namini et al., 2014). The complexity of sustainability rating systems has been found to hinder widespread adoption of these practices (Berardi, 2012). Rogers, in his innovation diffusion theory, maintains that complexity of an innovation can affect its adaptation. It is noted that the economic aspects of buildings has been ignored in many rating tools. BREEM and LEED do not consider social or economic criteria when rating a building (Berardi, 2012). DGNB is the only rating system that considers economic aspects (Green Building Council Denmark, n.d.). Moreover, all thirdparty building rating systems are not comprehensive, as they do not simultaneously address social, environmental and economic aspects. Despite the large body of knowledge, a limited number of rating systems have survived. Nguyen and Altan (2011) compared building sustainability rating systems based on multiple criteria (i.e. popularity and influence, availability, methodology, applicability, user friendliness, accuracy and verification and data collection process) (Nguyen \& Altan, 2011). This study has identified LEED and BREEM as rating systems with strong bases. Performance assessments of infrastructure should look into various perspectives, such as the agency's viewpoint (performance related to municipality objectives), users' viewpoint (performance related to user requirements) and the community's viewpoint (i.e. infrastructure performance related to community objectives) (Transportation Research Board, 2013). Hence, building performance management could be improved by studying the specific needs of user groups. Rating systems do not currently accomplish this task (Huang et al., 2013; Lai \& Yik, 2009). Moreover, the abovementioned rating systems do not facilitate continual building performance assessment, which is an important consideration for building performance management. LOS can 
be a continual performance assessment method for building performance due to its adaptation in other infrastructure categories.

\subsection{Level of Service}

Infrastructure that fails to meet LOS standards reduces the quality of life for users, the ability to support economic development and the safety of residents (Sharma, Al-Hussein, et al., 2008). The concept of LOS was initially developed for roads and later extended to other infrastructure classes. Ireland, Fearon, \& Hawker, (2008) defined LOS as the performance of an asset. Félio \& Lounis, (2009); Federation of Canadian Municipalities, (2002) identified LOS as an assessment of the quality of the service provided with respect to the society and economy. Assessing the LOS assists infrastructure managers in the following aspects (Federation of Canadian Municipalities, 2002):

- Promoting sustainable practices

- Supporting decision making related to investment planning and management

- Facilitating community involvement by managing the infrastructure asset

The determination of LOS facilitates municipal decision makers in prioritizing the infrastructure assets in investment planning related to expansion, operation and maintenance, rehabilitation, and replacement of infrastructure (Ireland et al., 2008). It is important to determine the performance measures and indicators needed to set and monitor the LOS (Han et al., 2015). LOS is a central part of sustainable asset management that combines a strategic asset management plan and an asset condition assessment (Z. Khan, Moselhi, \& Zayed, 2009). The process for establishing LOS could differ based on the type of infrastructure asset (Federation of Canadian Municipalities, 2002). LOS indicators incorporate social, environmental, and economic plans of a community, and could change from one community to another (Z. Khan et al., 2009). 
Figure 1 illustrates performance associated with the LOS. According to Infrastructure Canada (2002), LOS of infrastructure is assessed based on the criteria such as, safety, customer satisfaction, quality, quantity, capacity, reliability, responsiveness, environmental acceptability, cost, and availability (Federation of Canadian Municipalities, 2002; Félio \& Lounis, 2009; Ireland et al., 2008).

\subsubsection{Level of Service of Buildings}

Based on the above definitions, LOS for public building infrastructure can be defined as an assessment of the operational performance provided to the building users and society. Environmentally conscious performance is embraced by the contemporary world. Hence, environmental consciousness is an important parameter in defining the building service. Operational performance provided to users is being assessed based on the LOS performance categories defined by (Federation of Canadian Municipalities, 2002).

\section{Level of Service}

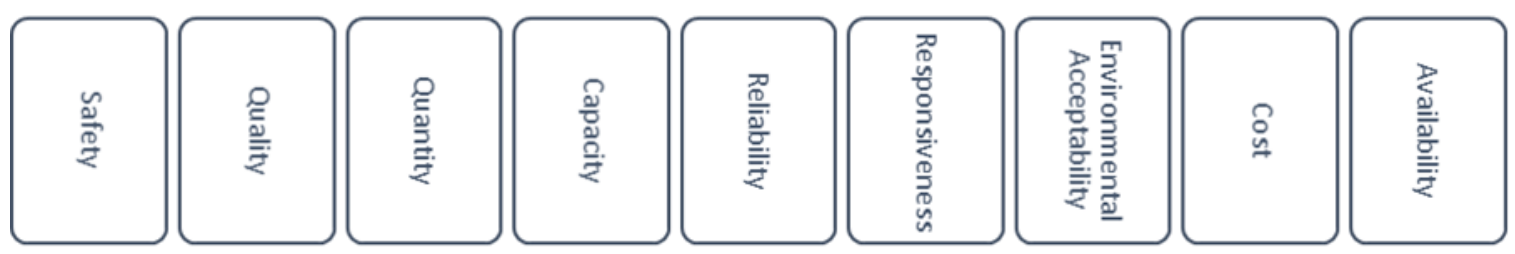

Figure 1: LOS categories

Each parameter that defines LOS is explained below.

Safety: Safe buildings should ensure healthy indoor air quality, ergonomic design, electrical safety and accident prevention. In addition, the building should include measures to prevent potential 
natural and human-caused hazards to the building users (National Institute of Building Sciences, 2015).

Quality: A building's facilities management services should be of high quality, reaching the expected quality of key stakeholders (Ahmad et al., 2009)(Lepkova \& Ūselis, 2013).

Quantity: Quantity is the ability of buildings to serve the current demand for a building.

Capacity: Capacity assesses the ability of a building to serve expected service demand in future.

Reliability: Capability to perform a service dependently and accurately (Parasuraman, Zeithaml, \& Berry, 2016).

Responsiveness: Readiness to help customers and provide speedy service (Parasuraman et al., 2016).

Environmental Acceptability: Environmental acceptability assess the environmental performance of the building

Cost: Cost effective building should be the desire of every building manager. Cost effective building operation should include attributes such as low building operation and maintenance costs and longer life span (National Institute of Building Sciences, 2012)

Availability: Agreed service time of the infrastructure asset to perform the agreed service function (Office of Government Commerce, 2007)

Cao et al. (2015) identified user satisfaction as an important parameter in post occupancy evaluation of buildings. Insufficient operation and maintenance would result in service quality and user dissatisfaction (Siu, Bridge, \& Skitmore, 2001).

Stakeholders of municipal infrastructure system includes municipality (Agency), persons who are using the asset (Customer) and the community. The aforementioned stakeholders have different expectations from the municipal infrastructure system. LOS defines the terms of reference for 
quality of service provided from an infrastructure system (Z. Khan et al., 2009). According to Han et al (2015) LOS include two paradigm, customer perspective and mangers perspective (Han et al., 2015). Sharma et al. (2008) suggested that user expectations, legislative requirements, performance standards, budget limitations, and delivery mechanisms should be considered when setting up a target LOS (Sharma, Al-Hussein, et al., 2008).

According to Transportation Research Board (2006), agencies target their expected service level by tracking track performance over time (Transportation Research Board, 2006). The agency, managing the asset, has to pool considerations from the customer and society. According to Transportation Research Board (2006), the factors that are considered in setting up a target LOS for a road system include the following (Transportation Research Board, 2006):

- Expected funding levels;

- Policy goals of the organization, regional priorities, or priorities by route classification;

- Public opinion;

- Present condition, past performance trends,

- Internal and external input and discussions with the construction industry;

- Life cycle cost and trade-off analyses;

- Marginal value of additional investment;

\subsection{Level of Service Assessment}

The literature review indicates that there is no standard method to assess the LOS of infrastructure as several methods have been used in calculation of LOS. One of the study viewed LOS from various users of the infrastructure asset. Sharma et al. (2008) used pedestrian LOS, bicycle LOS and vehicle LOS when assessing the overall asset LOS of municipality/urban roads (Sharma, Al- 
hussein, et al., 2008). Han et al. (2015) used a hierarchical framework to assess LOS related to water infrastructure focusing on TBL of sustainability (Han et al., 2015). This study has been conducted by using a customer survey. A psychometrical scaling technique was adopted by Correia and Wirasinghe (2008) to assess the LOS of airport departure lounges (Correia \& Wirasinghe, 2008). This approach adopted surveys where passengers were requested to rate service characteristics relative to preference, importance, and satisfaction. The above mentioned approaches are primarily survey based, which requires significant resources. However, these surveys do not look into wider performance categories (defined in Figure 1) associated with the LOS. The use of an objective approach in the assessment of LOS would ease the present challenges in LOS assessment.

LOS occurs at multiple levels, e.g. components, assets, systems and agency wide (USEPA, 2010). The same concept could be adopted for building infrastructure (Figure 2). As illustrated in Figure 2, LOS of building components (e.g. window) would facilitate in achieving LOS of building systems (e.g. building envelope). LOS of building systems would enable achieving the LOS of the overall building. USEPA, (2010) defined the aforementioned as roll up LOS.

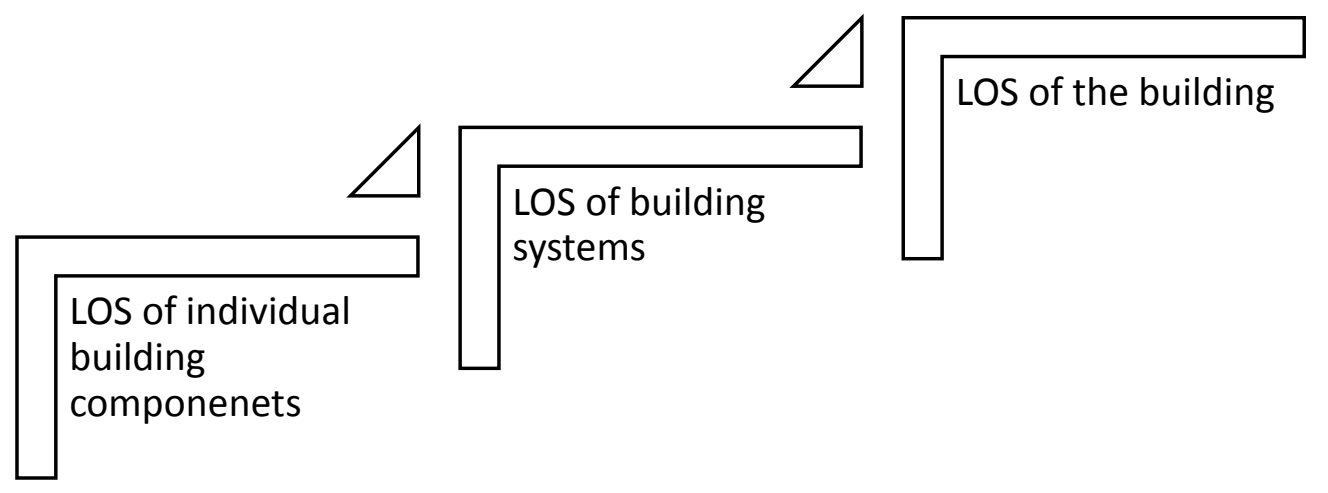

Figure 2: LOS propagation for buildings

LOS occurs at both asset and customer levels (USEPA, 2010). According to USEPA, (2010) there are internal and external LOS targets (USEPA, 2010). External LOS are strategic targets that are 
determined by customer demand and local legislative body requirements (e.g. building level) (USEPA, 2010). Internal LOS targets are tactical and focus on management operations (e.g. component, system and building level).

\subsection{Using LOS for Building Asset Management}

Adopting from the roll up LOS, Figure 3 illustrates how condition of components and systems will affect the overall building condition rating. As presented in Figure 3, condition rating of the building depends on the system and component condition rating. The condition rating of a component depends on component performance indicators (CPI), including physical condition of the component, energy efficiency, noise level etc. The condition rating of the system components and system performance indicators (SPI) defines the condition rating of the system (e.g. HVAC system, building envelope). The condition ratings of systems and building performance indicators (BPI) define the condition rating of the building.

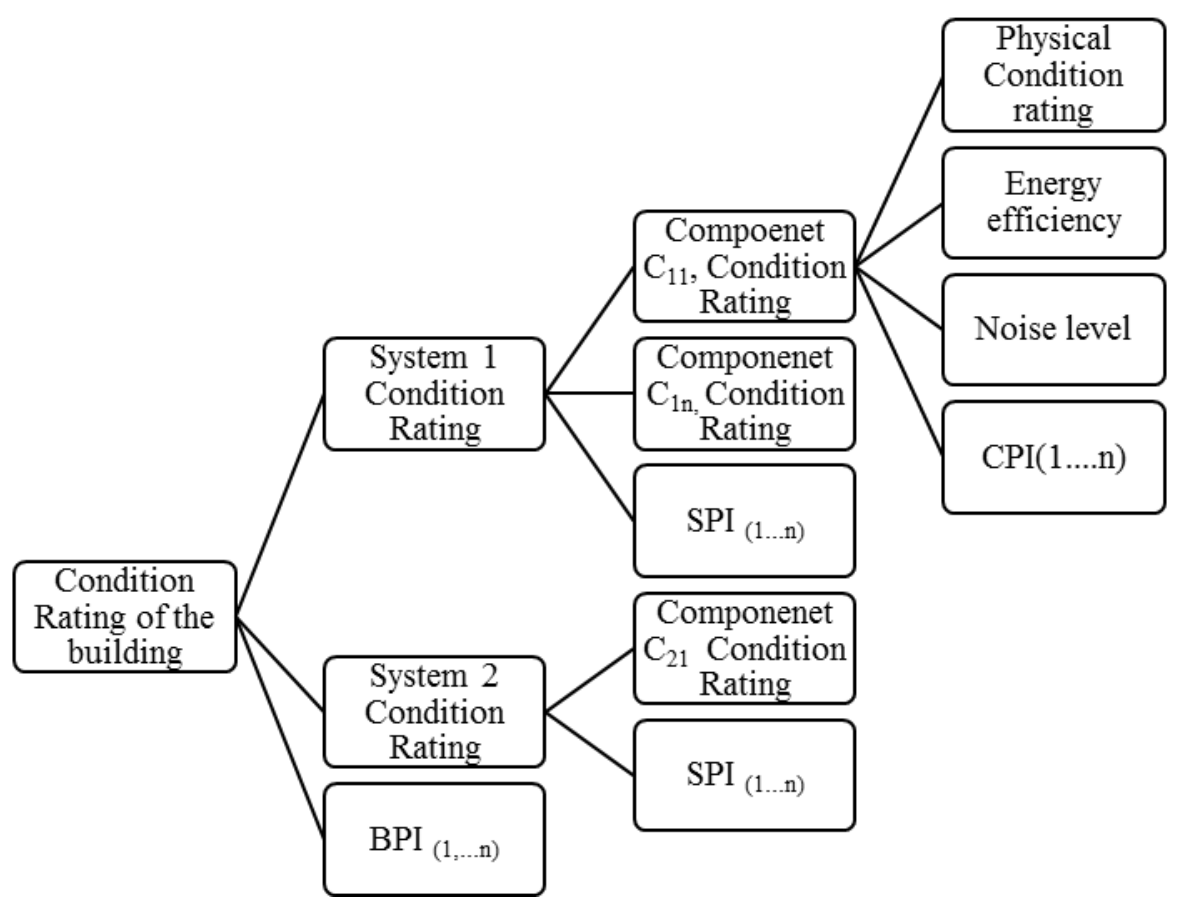

Figure 3: Defining condition rating of the building 
Strategic, tactical and operational management of municipality could use this information to enhance the asset management practices of the municipality. As an example, strategic management will define vision for the institution (e.g. eco-centric), tactical management will define operational LOS targets and performance benchmarks, and operational management will monitor the building performance and report the performance gaps to the higher management. This task would be further informed by public opinion. Furthermore, performance gaps and resource demands will redefine the LOS targets of the building (Figure 4).

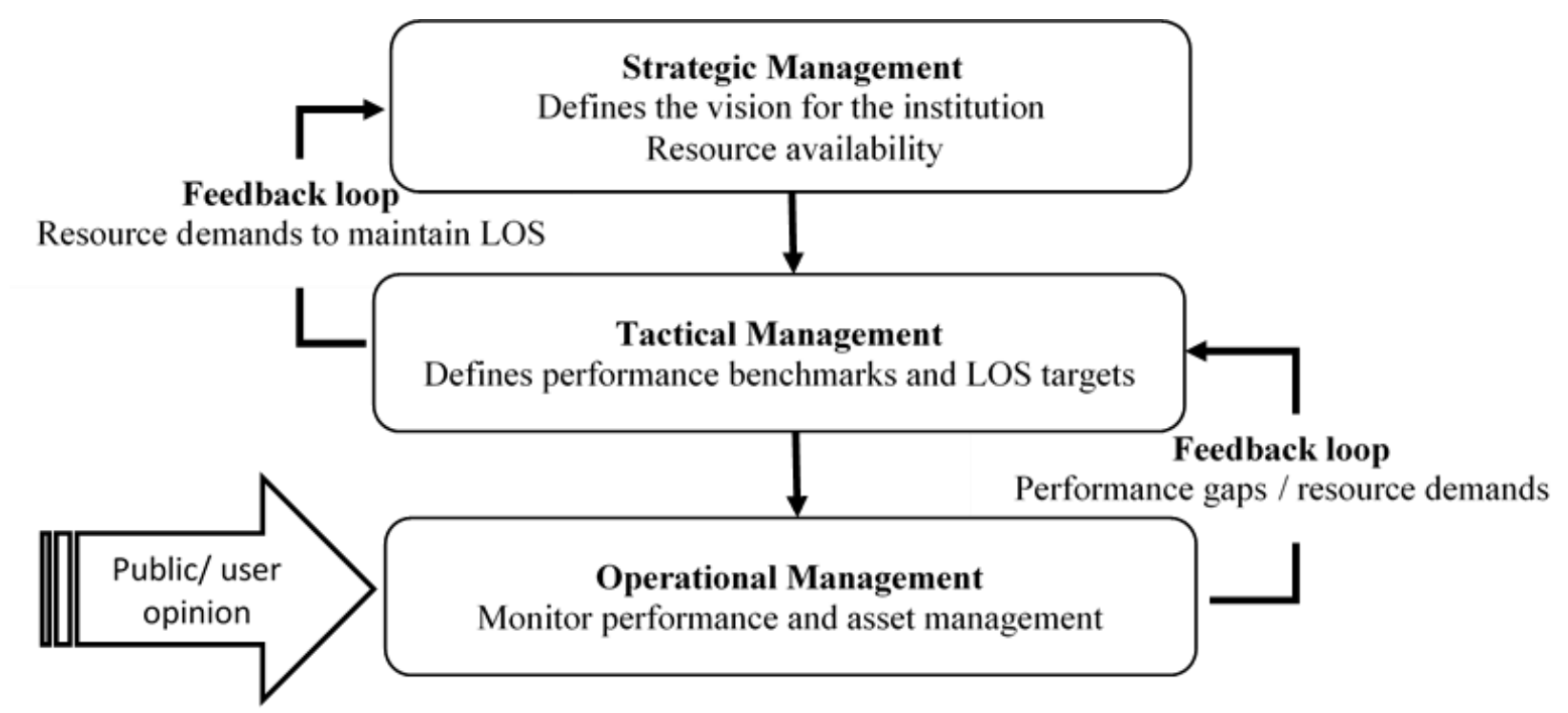

Figure 4: Building asset management by a public sector institution

\section{Methodology}

A comprehensive framework was developed to assess the LOS of buildings. This approach incorporates FSE in assessing the building performance. Proposed framework includes sequential steps in assessing the LOS of building infrastructure. 


\subsection{Fuzzy Set Theory}

Fuzzy set theory is a powerful mathematical model to characterize uncertainty in reality (Zadeh, 1965; Zimmermann, 2010). After being introduced by professor Lofti A. Zadeh in 1965, fuzzy set theory has been used in a vast range of disciplines such as engineering, logistics, management, and data processing (Zimmermann, 2010). This theory is a useful method to be used in decision support due to its ability to deal with imperfect information about the reality.

Fuzzy number describes the membership function $(\mu)$ of an uncertain variable $(x)$ that ranges between 0-1 (Sadiq et al. 2004). Equation 1 presents the basic definition of the fuzzy set theory. The fuzzy set $\tilde{A}$ is denoted as a set of ordered pairs in a universe of $X$, where $x$ denotes the objects of $X$. The membership function, $\mu_{\tilde{A}}(x)$, maps $x$ values to $\tilde{A}$ in the interval 0 to 1 .

$\begin{array}{ll}\tilde{A}=\left\{\left(x, \mu_{\tilde{A}}(x) \mid x \in X\right)\right\} & \text { Equation } 1\end{array}$

Uncertainties related to the performance of infrastructure systems can be modelled using fuzzy numbers. Fuzzy synthetic evaluation and fuzzy composite are two techniques that can be used for LOS evaluation of the public aquatic centre buildings. FSE has been commonly used in decision making scenarios with uncertain information (Rehan Sadiq, Husain, Veitch, \& Bose, 2004; Rehan Sadiq \& Rodriguez, 2004; Umer, Hewage, Haider, \& Sadiq, 2016).

\subsection{Fuzzy Synthetic Evaluation (FSE)}

Deterministic evaluation of an ill-defined object can be complex, vague, and distant from the reality. FSE is a process of evaluation where several individual elements and components are synthesised into an aggregate form. FSE can be used to handle uncertainties associated with information data, aggregated categories, and overall index rating (Umer et al., 2016). FSE 
accommodates both numerical and non-numerical data in evaluation by adopting linguistic terms (Ross, 2005).

Following example explains FSE in detail. LOS performance of a building is evaluated based on performance categories such as safety, quality, reliability etc. LOS performance level of a building is measured using a linguistic scale (i.e. excellent, superior, adequate, and inferior). After consultation with experts, a membership could be developed that assign relations between different perspectives. $\underline{\mathrm{R}}$ represents the fuzzy relationship between performance factors and level.

$$
\underline{R}=\begin{gathered}
\text { Safety } \\
\text { Quality } \\
\text { Reliability }
\end{gathered}\left[\begin{array}{ccccc}
\text { Excellent } & \text { Superior } & \text { Adequate } & \text { Inferior } \\
0.8 & 0.5 & 0.3 & 0 \\
0.1 & 0.2 & 0.5 & 0.7 \\
0.1 & 0.3 & 0.5 & 0.8 \\
. & . & . & .
\end{array}\right]
$$

The performance of a selected building is provided as membership to performance categories $(w)$.

$$
\begin{gathered}
W=\left\{W 1, W 2, W 3, \ldots \ldots, W_{n}\right) \\
\text { Where } \sum_{i} w_{i}=1
\end{gathered}
$$

Fuzzy vector (e) contain membership values for each building for performance levels (Equation 2).

$$
\underbrace{e}_{w}=w^{\circ} \underbrace{R}_{w}
$$

\subsection{Rationale for using FSE for LOS assessment}

Building performance is defined using qualitative and quantitative performance indices. Uncertainties are inherent in the performance evaluation of infrastructure systems. Due to the fuzziness of information, performance indicators of infrastructure systems can be estimated with different levels of certainty (most likely, minimum and maximum). Benchmarks for infrastructure performance too are associated with significant uncertainties and subjectivity (e.g. LOS). Therefore, FSE is used for the performance evaluation of building infrastructure. Ruparathna, et 
al. (2015) have used FSE for LOS assessment of recreational centre buildings. The proposed performance management index, as outlined below, involves four steps in calculating the performance of a public building (Khatri, Vairavamoorthy, \& Akinyemi, 2011; Ruparathna et al., 2015) :

i. Identification and classification of performance indicators.

ii. Fuzzification of the performance indicators.

iii. Aggregation of LOS indicators and LOS performance categories using FSE.

iv. Defuzzification of the aggregated categories to calculate the total systems performance.

Figure 5 illustrates the methodology adopted for assessing the LOS of buildings. 


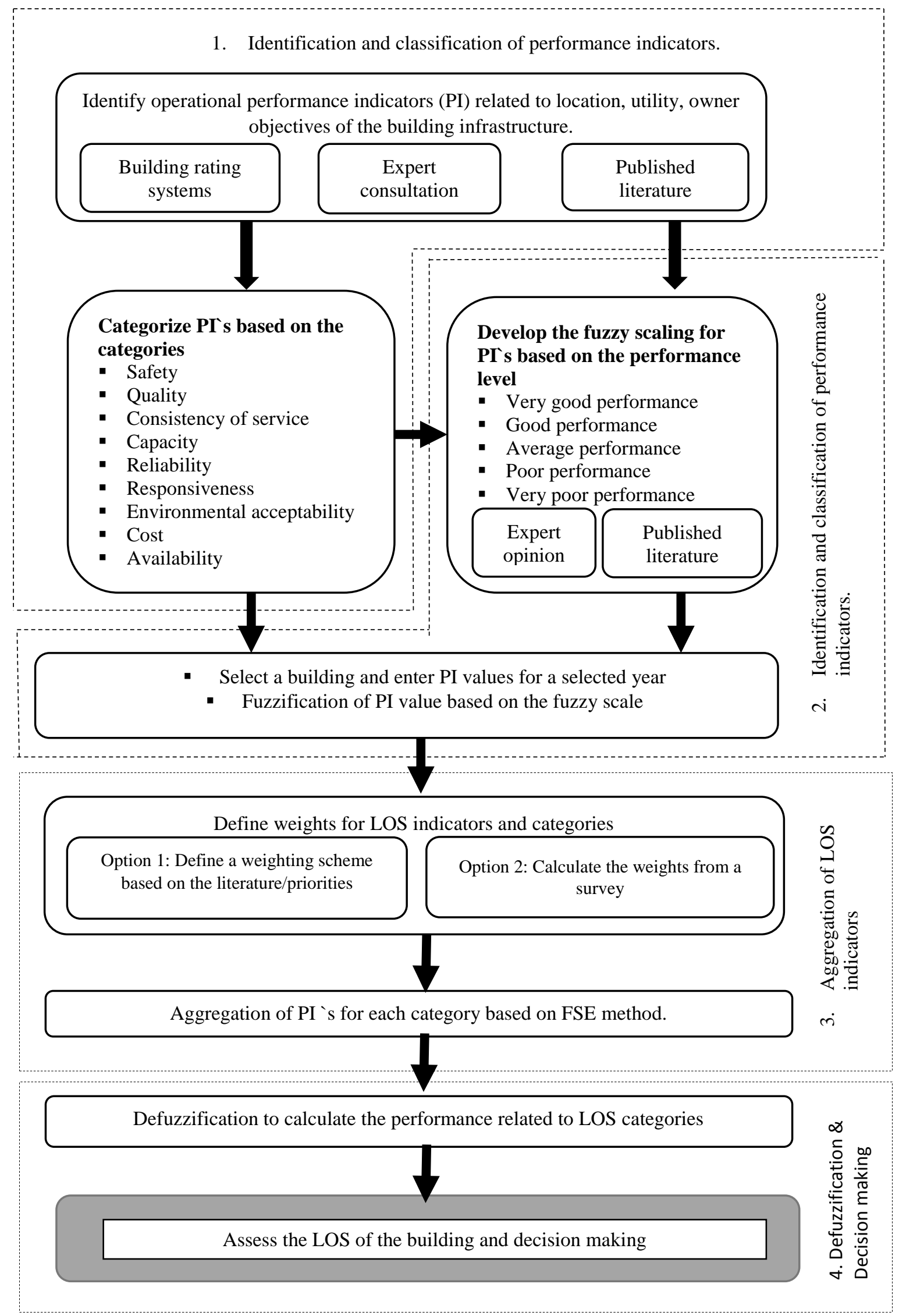

Figure 5: LOS assessment methodology 


\subsection{Identification and classification of indicators}

A comprehensive review was conducted to identify building operational performance indicators (Appendix A). However, indicator based systems have been commonly used in the literature to assess the sustainability performance of civil infrastructure. As an example, Dasgupta \& Tam (2005) proposed an indicator based multilayered screening process to compare alternatives for civil infrastructure systems (Dasgupta \& Tam, 2005). Published literature and established building rating methods were used to identify performance indicators. Table 1 presents the classified indicators according to the LOS categories. Indicators stated in Table 1 can be assigned to different levels in building asset hierarchy. Identified indicators include building performance indicators, system performance indicators, and component performance indicators. In this study, only building level indicators were focused on. 
Table 1: Classification of indicators

\begin{tabular}{|c|c|c|c|c|c|c|c|c|c|c|c|}
\hline $\begin{array}{l}\text { Applicable } \\
\text { to } \\
\text { Building (B) } \\
\text { / System (S) / } \\
\text { Component } \\
\text { (C) }\end{array}$ & Inc & icator & 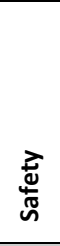 & $\frac{?}{\frac{2}{\pi}}$ & 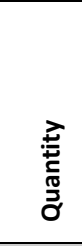 & $\begin{array}{l}\frac{Z}{0} \\
\frac{\pi}{0} \\
\frac{0}{0} \\
0\end{array}$ & 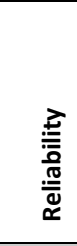 & 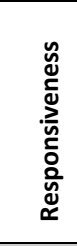 & 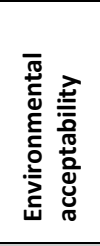 & 艹ัّ & 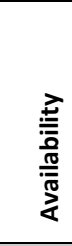 \\
\hline B & $\mathrm{I}_{1}$ & Availability of measures for protection against vandalism and security & $\checkmark$ & & & & & & & & \\
\hline $\mathbf{B}$ & $\mathrm{I}_{2}$ & User satisfaction level (Through a survey) & $\checkmark$ & $\checkmark$ & $\checkmark$ & $\checkmark$ & $\checkmark$ & $\checkmark$ & $\checkmark$ & $\checkmark$ & $\checkmark$ \\
\hline $\mathbf{B}$ & $\mathrm{I}_{4}$ & Thermal comfort to the users & & $\checkmark$ & & & & & $\checkmark$ & & \\
\hline B & $\mathrm{I}_{5}$ & Building cleanliness and visual comfort to the users & & $\checkmark$ & & & & $\checkmark$ & & & \\
\hline $\mathbf{B} / \mathbf{S} / \mathbf{C}$ & $\mathrm{I}_{6}$ & Indoor noise level & & $\checkmark$ & & & & & $\checkmark$ & & \\
\hline B & $\mathrm{I}_{7}$ & Indoor luminance level & & $\checkmark$ & & & & & & & \\
\hline $\mathbf{B}$ & $\mathrm{I}_{8}$ & $\begin{array}{l}\text { Adequacy of building amenities to users (Customizable based on the building } \\
\text { type) }\end{array}$ & & $\checkmark$ & & $\checkmark$ & & & & & \\
\hline $\mathbf{B} / \mathbf{S} / \mathbf{C}$ & $\mathrm{I}_{9}$ & Condition rating of building equipment & & & & $\checkmark$ & $\checkmark$ & & & & \\
\hline B & $\mathrm{I}_{11}$ & Number of deaths, injuries and illnesses while using assets or services & $\checkmark$ & & & & $\checkmark$ & & & & \\
\hline $\mathbf{B} / \mathbf{S} / \mathbf{C}$ & $\mathrm{I}_{12}$ & $\begin{array}{l}\text { Non planned service interruptions as a percentage to planned service } \\
\text { interruptions }\end{array}$ & & & & & $\checkmark$ & $\checkmark$ & & & \\
\hline B & $\mathrm{I}_{13}$ & Number of user days with no service interruptions & & & & & $\checkmark$ & $\checkmark$ & & & \\
\hline $\mathbf{B}$ & $\mathrm{I}_{14}$ & Quality of swimming pool water & & $\checkmark$ & & & & & $\checkmark$ & & \\
\hline $\mathbf{B} / \mathbf{S} / \mathbf{C}$ & $\mathrm{I}_{15}$ & Annual energy use intensity $\left(\mathrm{GJ} / \mathrm{m}^{2}\right)$ & & & & & & & $\checkmark$ & $\checkmark$ & \\
\hline B & $\mathrm{I}_{16}$ & Annual renewable energy consumption (As a proportion of the total energy) & & & & & & & $\checkmark$ & & \\
\hline B & $\mathrm{I}_{17}$ & Annual GHG emission reduction & & & & & & & $\checkmark$ & & \\
\hline $\mathbf{B}$ & $\mathrm{I}_{18}$ & Annual water consumption per user & & & & & & & $\checkmark$ & & \\
\hline B & $\mathrm{I}_{19}$ & Amount of water recycled as a $\%$ to waste water & & & & & & & $\checkmark$ & & \\
\hline $\mathbf{B} / \mathbf{S} / \mathbf{C}$ & $\mathrm{I}_{20}$ & Average cost of operation as a percentage of annual income & & & & & & & & $\checkmark$ & \\
\hline $\mathbf{B}$ & $\mathrm{I}_{21}$ & Amenities for persons with disability & & $\checkmark$ & & & & & & & $\checkmark$ \\
\hline $\mathbf{B}$ & $\mathrm{I}_{22}$ & Cycling convenience for the users & & $\checkmark$ & & & & & $\checkmark$ & & \\
\hline
\end{tabular}




\subsection{Fuzzification of the Performance Indicators}

In order to establish LOS, asset managers should have predefined target values and performance levels (Zafar Khan, Moselhi, \& Zayed, 2014). Literature defines standard performance levels for several indicators which could be used as benchmarks. Hence both standard benchmarks and manager defined benchmarks are proposed.

Methods adopted by Khatri et al. (2011), Rajini et al. (2006) and Umer et al (2016) were used to develop fuzzy sets for PI based on its association to the performance benchmarks (Khatri et al., 2011; Rajani, Kleiner, \& Sadiq, 2006; Umer et al., 2016). Benchmarks defined by building owners (Appendix B) were used to generate fuzzy sets. After fuzzification, each PI is expressed as a pentadruple fuzzy number (PFN). Performance level associated PIs can be in multiple forms, monitored crisp value (i.e. energy consumption: $6000 \mathrm{GJ}$ per year), monitored uncertain value (i.e. condition rating of building components: 6-7) and qualitative value (i.e. building cleanliness and visual comfort: average). Highest membership value for performance level was selected for multiple intersections. Similar to Umer et al., (2016), pseudo numeric values were used to fuzzify and plot qualitative fuzzy numbers (Umer et al., 2016).

\subsubsection{Aggregation of LOS indicators and LOS performance categories using FSE}

The aggregation operation involves of combining PIs level performances to upper levels (i.e.

performance category (PC) and building). The hierarchical process is presented in Figure 6. PFN of PI were aggregated to calculate the performance related to LOS categories. LOS performance categories were aggregated to calculate the LOS of the overall building. Weighted sum method was used to aggregate PIs and PCs. Weights were defined according to the priorities of the public sector institution. 


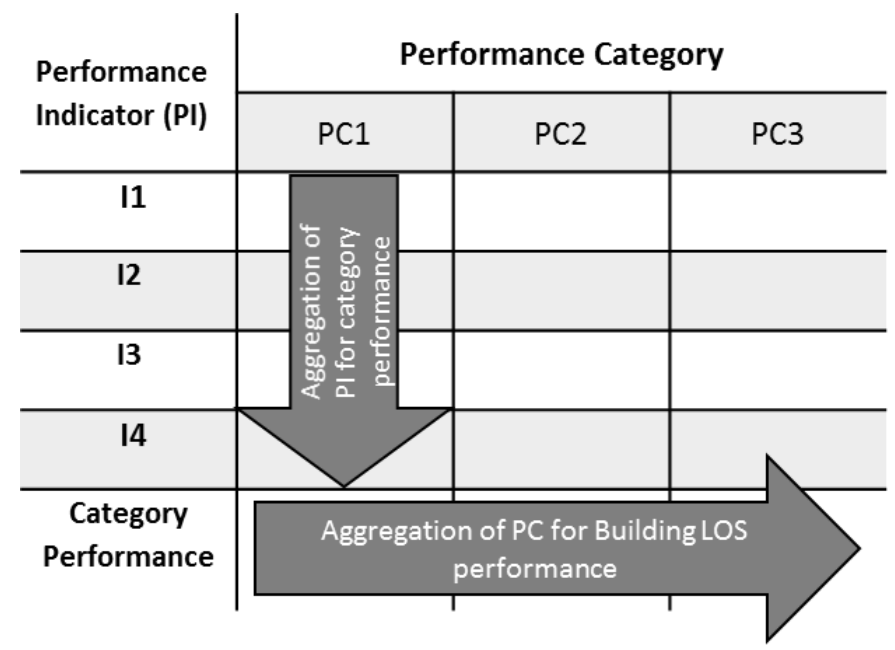

Figure 6: Aggregation of PI and PC to calculate LOS

\subsubsection{Defuzzification of the Aggregated Indexes to Produce the Overall Systems}

\section{Performance}

PFN derived for performance categories and the building would be made a crisp number through defuzzification operation. A commonly used defuzzification method, the centroid method, would be used for defuzzification operation. Overall LOS index is calculated using Equation 3.

$L O S I=D_{1} C^{T}$

Equation 3

Where,

$\mathrm{C}^{\mathrm{T}}=$ Transpose of a vector of centroid values of the membership functions

$\mathrm{D}=$ Performance of a category/building

\section{Case study}

The proposed generic framework was customized for an aquatic centre buildings owned and operated by the public-sector institutions. The proposed approach was demonstrated through a case study on an operating aquatic centre building in Okanagan, BC, Canada. A public sector institution was contacted to obtain performance data for LOS data. Building performance level were defined 
using TFN. Building LOS performance levels defined by Nilashi et al., (2015) were used (Table 2) (Nilashi et al., 2015).

Table 2: TFN for building performance

\begin{tabular}{l|lllll} 
PERFORMANCE & $\begin{array}{l}\text { VERY } \\
\text { LOW }\end{array}$ & LOW & MODERATE & HIGH & $\begin{array}{l}\text { VERY } \\
\text { HIGH }\end{array}$ \\
\hline TFN & $-0.2,0,0.2$ & $0,0.2,0.4$ & $0.3,0.5,0.7$ & $0.6,0.8,1$ & $0.8,1,1.2$
\end{tabular}

Table 3 presents monitored PI values and fuzzified PI value. PI Fuzzification was performed considering the benchmarks defined in Appendix B. 
Table 3: Monitored indicator values and analysis

\begin{tabular}{|c|c|c|c|c|c|c|c|c|c|}
\hline \multirow[b]{2}{*}{ Indicator } & \multirow[b]{2}{*}{$\begin{array}{c}\text { Target LOS } \\
\text { Performance }\end{array}$} & \multirow[b]{2}{*}{ Unit } & \multicolumn{5}{|c|}{ Membership Value } & \multirow[b]{2}{*}{$\begin{array}{l}\text { Monitored } \\
\text { Performance }\end{array}$} & \multirow[b]{2}{*}{$\begin{array}{l}\text { LOS } \\
\text { Achieved }\end{array}$} \\
\hline & & & 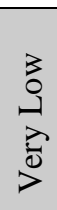 & 3 & $\begin{array}{l}\frac{0}{\pi} \\
\frac{\pi}{0} \\
\overline{0} \\
\Sigma\end{array}$ & 焉 & 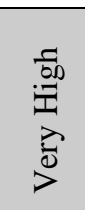 & & \\
\hline $\mathbf{I}_{\mathbf{1}}$ & Good & Qualitative & 0 & 0 & 1 & 0 & 0 & Moderate & No \\
\hline $\mathbf{I}_{2}$ & Very Good & Qualitative & 0 & 0 & 0 & 1 & 0 & Very Good & Yes \\
\hline $\mathbf{I}_{3}$ & Very Good & Qualitative & 0 & 0 & 0 & 0.76 & 0.76 & Good & No \\
\hline $\mathbf{I}_{4}$ & $22-24$ & ${ }^{\circ} \mathrm{C}$ & 0 & 0 & 0.34 & 0.66 & 0 & $23-25$ & No \\
\hline $\mathbf{I}_{5}$ & Very Good & Qualitative & 0 & 0 & 0 & 0.76 & 0.76 & Good & No \\
\hline$I_{6}$ & $40-45$ & $\mathrm{~dB}$ & 0 & 0 & 0 & 0 & 1 & 30 & Yes \\
\hline $\mathbf{I}_{7}$ & $500-600$ & lumans $/ \mathrm{m}^{2}$ & 0 & 0 & 0 & 1 & 1 & 450 & Yes \\
\hline $\mathbf{I}_{8}$ & Very Good & Qualitative & 0 & 0 & 0.66 & 0.32 & 0 & Very Good & Yes \\
\hline I9 & Good & Qualitative & 0 & 0 & 0.5 & 0.74 & 0.25 & Moderate & No \\
\hline $\mathbf{I}_{10}$ & Good & Qualitative & 0 & 0 & 0 & 1 & 0.34 & Moderate & No \\
\hline $\mathbf{I}_{11}$ & 0 & Incidents & 1 & 0 & 0 & 0 & 0 & 3 & No \\
\hline$I_{12}$ & $2 \%$ & Ratio & 0 & 0.5 & 0.5 & 0 & 0 & $2.5 \%$ & No \\
\hline $\mathbf{I}_{13}$ & 0 & Ratio & 0 & 1 & 0 & 0 & 0 & $98 \%$ & No \\
\hline $\mathbf{I}_{14}$ & Good & $\begin{array}{l}\text { Qualitative/ } \\
\text { Quantitative }\end{array}$ & 0 & 0 & 0 & 0.66 & 0.66 & Good & Yes \\
\hline $\mathbf{I}_{15}$ & 500 & $\mathrm{kWh} / \mathrm{m}^{2}$ & 0 & 0 & 0 & 0 & 1 & 426 & Yes \\
\hline $\mathbf{I}_{16}$ & 10 & Percentage & 0 & 0 & 0 & 1 & 0 & 5 & Yes \\
\hline $\mathbf{I}_{17}$ & $0 \%$ & Percentage & 0 & 0 & 0 & 0.28 & 0 & $2 \%$ & No \\
\hline $\mathbf{I}_{18}$ & 100 & $\mathrm{~m}^{2} /$ user/year & 0 & 0 & 1 & 0 & 0 & 90 & Yes \\
\hline$I_{19}$ & $40 \%$ & Percentage & 0 & 0 & 0 & 0.5 & 0 & $30 \%$ & No \\
\hline$I_{20}$ & Good & Cost/Income & 0 & 0.5 & 0.5 & 0 & 0 & Good & Yes \\
\hline $\mathbf{I}_{21}$ & Moderate & Qualitative & 0 & 0 & 0 & 1 & 0 & Moderate & Yes \\
\hline$I_{22}$ & Good & Qualitative & 0 & 0 & 0 & 1 & 0 & Moderate & No \\
\hline
\end{tabular}

According to Table 3, the building did not achieve the target LOS with regards to 12 of the LOS indicators. Fuzzy memberships of LOS categories are presented in Table 4. All LOS category has the highest membership high performance. 
Table 4: Memberships to LOS categories

\begin{tabular}{lrrrrrc} 
LOS Category & Very Low & Low & Moderate & High & Very High & Highest membership \\
\hline Safety & 0.25 & 0.00 & 0.25 & 0.44 & 0.19 & High \\
Quality & 0.00 & 0.00 & 0.11 & 0.71 & 0.38 & High \\
Quantity & 0.00 & 0.00 & 0.33 & 0.66 & 0.00 & High \\
Capacity & 0.00 & 0.00 & 0.39 & 0.69 & 0.08 & High \\
Reliability & 0.17 & 0.25 & 0.17 & 0.46 & 0.10 & High \\
Responsiveness & 0.00 & 0.38 & 0.13 & 0.44 & 0.19 & High \\
Environmental & 0.00 & 0.00 & 0.13 & 0.51 & 0.27 & High \\
acceptability & & & & & & High \\
Cost & 0.00 & 0.25 & 0.25 & 0.50 & 0.00 & High \\
Availability & 0.00 & 0.00 & 0.00 & 0.67 & 0.33 &
\end{tabular}

Figure 7 illustrates performance related to LOS categories after defuzzification. Performance related to LOS category is highest related to quality. Performance related to other LOS categories are in the following order, availability, capacity, environmental acceptability, quantity, responsiveness, safety, reliability, and cost.

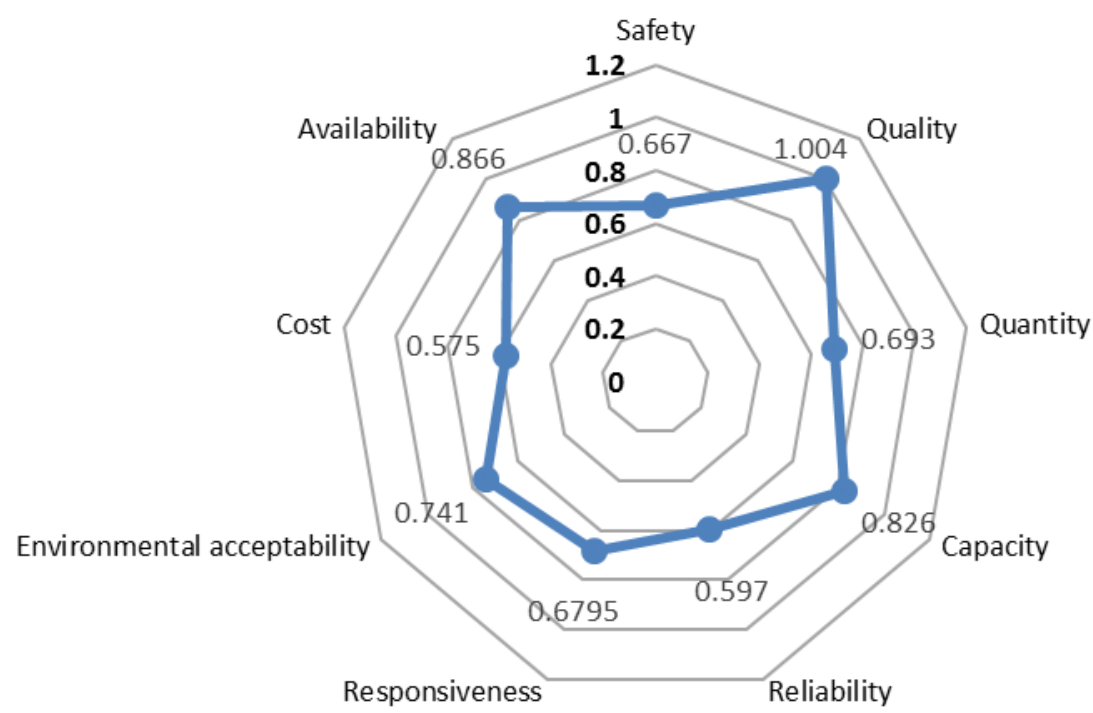

Figure 7: Performance related LOS categories 


\subsection{Weight Schemes for Overall Building Performance Assessment}

Priorities of municipalities differ from one to another. Hence, universal weights for PIs and PCs cannot be defined. Weight schemes have been used by previous researchers to mitigate uncertainty of user priorities (Umer et al., 2016). This analysis adopted three weight schemes. Weight schemes and performance benchmarks were established with the consultation of the municipality and literature.

User defined: Consultations with infrastructure and planning group of the municipality was conducted to determine performance benchmarks and PC weights. Equal weights were assigned to PCs.

Pro-Environment: In this pseudo scenario, environmental performance has been given prominence. Environmental performance category was assigned higher weight. Equal weight were assigned to other PCs.

Service oriented: In this pseudo scenario service provided by the facility is given prominence. Equal weights were assigned to service related performance categories. Environmental performance and cost were assigned low weights.

Membership of overall building performance for three scenarios are presented in Table 5.

Table 5: Membership of overall building performance

\begin{tabular}{lllllll|} 
LOS Category & Very Low & Low & Moderate & High & Very High & Highest membership \\
\hline User defined: & 0.05 & 0.10 & 0.19 & 0.56 & 0.17 & High performance \\
Service oriented & 0.06 & 0.13 & 0.25 & 0.72 & 0.21 & High performance \\
$\begin{array}{l}\text { Pro- } \\
\text { Environment }\end{array}$ & 0.04 & 0.09 & 0.19 & 0.56 & 0.18 & High performance \\
\hline
\end{tabular}


Overall building performance is presented in Table 6. According to the analysis, the overall building performance is high and does not change based on the user priorities.

Table 6: Building LOS for different scenarios

$\begin{array}{llll}\text { Scenario } & \text { Pro-Environment } & \text { Service oriented } & \text { User defined } \\ \text { Building performance } & 0.74 & 0.95 & 0.74\end{array}$

\section{Discussion}

Operational performance assessment of buildings has received ample attention during the recent past. Despite providing a snap shot view, commonly used performance rating systems do not provide adequate information on managing the operational performance of buildings. LOS is commonly adopted by infrastructure managers in managing the service provided to the public. Hence, LOS could be adopted to sustain the service provided by public buildings.

This paper is an extension to the LOS assessment approach for recreational buildings proposed by Ruparathna, et al. (2015). The proposed approach uses FSE, which enables the use of incomplete, qualitative and vague data in the analysis. LOS assessment approach was demonstrated using a case study of an aquatic centre building operating in Okanagan, BC. Furthermore, in order to demonstrate this method, various weight scenarios were analyzed to illustrate the how priorities of the municipality affect the LOS of the building. The proposed framework was customized to assess the LOS of a public aquatic centre building operating in Okanagan, BC Canada. The overall LOS of the building had the highest membership to high performance in all three weight schemes. Performance related to LOS categories had the highest membership to high category. However, the building did not achieve the target performance in 12 LOS indicators. Hence, building operators should more focus on the performance related to individual performance indicators. 
Three levels of above information would provide detailed information in managing the operational performance of the building in focus.

This approach has incorporated the multidimensional nature of operational indicators on LOS of buildings, thus resolving a shortcoming associated with previous work highlighted in section 2.1. Building LOS approach combines asset management, build operational rating, and facilities management. Hence, the LOS based approach incorporates a holistic view on the operational performance of a building. This research provides a unique assessment of the performance of a building asset by focusing on the condition rating of component level and system level to define the overall condition rating of the building. This scrutinized information assists asset management and resource allocation decision making by comparison of the physical condition rating related to building, components and systems. Component level and system level condition rating will identify poorly performing building components and systems, thereby assisting building managers in implementing maintenance, repair and renovation of buildings. Building level LOS indicates the service provided to the building users. This approach identifies underperforming LOS categories where the service could be improved by allocating more resources, by improving processes, and by retrofitting. Several initiatives that could improve the LOS include energy retrofitting, improving the safety/security arrangements, and improving facilities management services. The cost implications could be weighed against target LOS to identify the optimal LOS that could be delivered under the available budget.

The proposed approach can be implemented as an internal building performance management strategy. Here top-bottom approach can used to set performance targets (building and category level) and resource allocation. A bottom-up approach can be used for performance monitoring of the building operations. LOS evaluation informs building users about the status of building service 
performance. More importantly, this information ensures the transparency of municipality operations since the facility is operated by tax dollars/ subscriptions. The proposed rating system can be implemented by the infrastructure department of the municipality. This approach could be a common basis to compare operational performance of municipal building categories. Presently, LOS is assessed for key municipal infrastructure classes. Hence, the proposed method would add into the existing system. This approach would enable annual performance monitoring of the building. The proposed approach provides the building performance related to two hierarchical levels (i.e. overall performance and categorical performance). Corrective actions could be initiated if the performance of the building is below the pre-established targets. Corrective action triggers could be related to the overall performance and categorical performance. Using the LOS enables comparing the LOS of a building with other buildings and other classes of infrastructure. Besides being an internal performance management approach, LOS could be used for continuous reporting of the services provided to users. Reported LOS would inform building users in comparing and selecting recreational facilities such as aquatic centres. Furthermore, the building level (final synthesized level) performance could be used as an indicator of a comprehensive building sustainability rating system.

The municipality should define the benchmarks for the LOS based on organizational priorities. Overall LOS rating of a building is influenced by both pre-established performance benchmarks and category weights. This is one of the unique features of the proposed approach. Furthermore, LOS targets are established for several performance categories. As a responsible organization, a municipality should establish constructive performance benchmarks. Benchmarks could further be adopted to improve the service provided by the building. Benchmarks and category weights could be adopted to define the priorities of the building owners. 
Building LOS is evaluated by performance related to indicators through monitored performance, annual user survey and the expert judgement of the building manager. Even though building level indicators are commonly available, obtaining performance related to component and system level indicators can be a challenge. As an example, component and system LOS assessment requires energy used by the specific component/system. Since energy sub-metering has not been fully incorporated into building management, obtaining specific energy demand could be a challenge. Component/ system condition is proportional to the energy consumption. Hence, assumptions can be made for component / system energy efficiency using mathematical models. Furthermore, this process requires extensive data for all stakeholders. Shoolestani et al (2015) proposed an approach that allows occupants to interact with building and provide feedback on buildings using building information modelling (e.g. SocioBIM (Shoolestani, Shoolestani, Froese, \& Vanier, 2015b). The proposed system could be integrated with a real-time data capturing approach that enable real-time LOS assessment of the building. User satisfaction depends on the number of incidents encountered. Thought this could be a future technology, real-time monitoring of LOS could assist in delivering the best service to the building users.

\subsection{Limitations of this study}

Four main limitations were identified in this research. First, equal weight was assumed for the performance indicators in calculating the scores of LOS categories. This could be calculated from weight calculation method (e.g. analytic hierarchy process, modified digital logic) through an expert survey. Since the objective of this research was to incorporate LOS concept into building infrastructure, weight schemes were used. Second, this study only assessed the LOS of the building. With additional data, LOS of components and systems could be evaluated. Due to lack of data, the aforementioned LOS at component and system levels were not evaluated. Third, the 
proposed approach was developed for public sector aquatic centre buildings as an internal building management method. Additionally, several of the defined benchmarks were specifically for the local government's requirement. Hence, this approach could be used in different context by adjusting benchmarks and category weights. Finally, it is daunting to reasonably estimate the LOS of a building mainly due to its qualitative nature. This need was the rationale for this study. Assessment results can only be validated through expert consultation (a qualitative survey). Qualitative surveys are validated by saturation of the opinions of experts. This process can be extremely time intensive. Due to time limitations validation of the assessment was not conducted.

\section{Conclusions}

This research proposed a LOS assessment approach for building infrastructure and developed a LOS index for public recreational centre buildings. The proposed framework is an objective method for assessing performance. Proposed LOS based approach addresses a number of shortcomings in existing building performance evaluation methods. Additionally, the use of FSE enables incorporating vague, incomplete and qualitative data into the analysis. This approach would assist facilities managers in monitoring and managing the operational performance of public buildings. The proposed approach can be customized to suit the function of the public building, and institutional and geographical constraints by changing the indicators and benchmarks. Implementation of the proposed framework was demonstrated for a public aquatic centre building operating Okanagan, BC, Canada. This approach provided three levels of detail for operational management of public buildings.

Following recommended research would extend the findings of this study. First, this research uses FSE to aggregate the scores for LOS categories to calculate the overall LOS of the building. This approach loose significant information during the aggregation. Alternatively, fuzzy rules could be 
established to determine the overall LOS based on the performance of individual categories. This new approach will require input from building performance experts to establish fuzzy rules. Second, the proposed approach could be developed as a computer based tool for the building users. Authors are currently focusing on developing a working tool to be used by municipalities. The unique features of this tool include users' ability to alter benchmarks and weights based on their priorities and ability to incorporate vague and imprecise data. Third, the proposed method used chloramine concentration for indoor air quality (IAQ) of aquatic centre buildings. IAQ can be defined using number of sub indicators such as volatile organic compounds, microbial contaminants, fungi, moulds, bacteria for IAQ. Further research is needed to define each indicator in detail using sub indicators. This recommendation applies to indicators such as condition rating of the components/systems, where commonly used indicator such as facility condition index could be used instead of a qualitative rating scale. Finally, output from this research is aimed at improving the operational performance of public buildings by mobilizing tactical and operational management with easy-to-use resources with scientific backing. Despite a large number of building operational rating systems available in published literature, only a few have been accepted or recognised by the building industry. Hence, further research is required to assess the industry requirements and challenges for implementing similar approaches in the industrial context.

\section{Acknowledgements}

The authors would like to acknowledge FortisBC, the City of Penticton, and the collaborative research and development grants program of the Natural Sciences and Engineering Research Council (NSERC CRD) for funding this research. Last but not the least, the authors sincerely acknowledge Mr. Phil Hawkes of FortisBC and Mr. Chris Schmidt of the City of Penticton for providing case study data. 


\section{References}

Ahmad, Z., Universiti, B., Mara, T., Hadi, A., Universiti, N., Mara, T., ... Mara, T. (2009). Assessment of Property Management Service Quality of Purpose Built Office Buildings Assessment of Property Management Service Quality of Purpose Built Office Buildings. International Business Research, 2(1), 162-174. http://doi.org/10.5539/ibr.v2n1p162

Asadi-Shekari, Z., Moeinaddini, M., \& Shah, M. Z. (2012). A Disabled Pedestrian Level of Service Method for Evaluating and Promoting Inclusive Walking Facilities on Urban Streets. Journal of Transportation Engineering, 139(February), 120830034317000. http://doi.org/10.1061/(ASCE)TE.1943-5436.0000492

Asset Management BC. (2011). Guide for using the Asset Management BC Roadmap. British Columbia.

Atzeri, A. M., Cappelletti, F., Tzempelikos, A., \& Gasparella, A. (2016). Comfort metrics for an integrated evaluation of buildings performance. Energy and Buildings, 127, 411-424. http://doi.org/10.1016/j.enbuild.2016.06.007

Augenbroe, G., Castro, D., \& Ramkrishnan, K. (2009). Decision model for energy performance improvements in existing buildings. Journal of Engineering, Design and Technology, 7(1), 21-36. http://doi.org/10.1108/17260530910947240

BC Ministry of Health. (2014). B.C. Guidelines for pool design. Victoria, BC. Retrieved from http://www2.gov.bc.ca/assets/gov/environment/air-landwater/pool_design_guidelines_jan_2014_final.pdf

Berardi, U. (2012). Sustainability Assessment in the Construction Sector: Rating Systems and Rated Buildings. Sustainable Development, 20(6), 411-424. http://doi.org/10.1002/sd.532

BRE Global. (2012). Briefing Paper. BREEAM In-Use. Driving sustainability through existing buildings. Watford, UK. Retrieved from http://www.breeam.org/filelibrary/BREEAM In Use/KN5686---BREEAM-In-Use-White-Paper_dft2.pdf

BRE Global. (2015). Post-Occupancy Evaluation (POE). Retrieved January 11, 2016, from https://www.bre.co.uk/page.jsp?id=1793

Canada Green Building Council. (2009a). LEED® Canada for Existing Buildings: Operations and Maintenance 2009. Ottawa, ON.

Canada Green Building Council. (2009b). LEED® Canada for Existing Buildings: Operations and Maintenance 2009. Ottawa, ON. Retrieved from http://www.cagbc.org/AM/PDF/LEED Canada EBO\&M rating system.pdf

Canadian Centre for Occupational Health \& Safety. (2017). Emergency Planning. Retrieved January 21, 2017, from https://www.ccohs.ca/oshanswers/hsprograms/planning.html

Cao, Y., Wang, T., \& Song, X. (2015). Automation in Construction An energy-aware, agentbased maintenance-scheduling framework to improve occupant satisfaction. Automation in Construction, 60, 49-57. http://doi.org/10.1016/j.autcon.2015.09.002

Chasey, A. D., Garza, J. M. D. La, \& Drew, D. R. (1997). Comprehensive Level of Service: 
Needed Approach for Civil Infrastructure Systems. Journal of Infrastructure Systems, 3(4), 143-153. http://doi.org/10.1061/(ASCE)1076-0342(1997)3:4(143)

CIBSE. (2001). Energy use in sports and recreation buildings. Watford. Retrieved from http://www.cibse.org/getmedia/34def23a-c65b-405e-9dff-ce181c0b1e0d/ECG78-EnergyUse-in-Sports-and-Recreation-Buildings.pdf.aspx

City of Edmonton. (2012). City Operations Greenhouse Gas Management plan. Edmonton, AB. Retrieved from http://www.edmonton.ca/environmental/documents/CityOperationsGHGManagementPlan.p df

City of Nelson. (2013). Bicycle Parking Design Guidelines. Nelson, BC. Retrieved from http://www.nelson.ca/assets/City Services/Pubs and Reports/Development $\sim$ Services/Bicy cle Parking Design Guidelines.pdf

City of Saskatoon. (2009). Energy and GHG management plan. Saskatoon ,SK. Retrieved from http://www.saskatoon.ca/DEPARTMENTS/Utility Services/Environmental Services/climatechange/Documents/Sask Report June 09.pdf

City of Windsor. (2014). Greenhouse Gas Emissions Indicator. Retrieved from http://www.citywindsor.ca/residents/environment/Environmental-Master-Plan/Goal-D-UseResources-Efficiently/Pages/Greenhouse-Gas-Emissions.aspx

Correia, A. R., \& Wirasinghe, S. C. (2008). Analysis of level of service at airport departure lounges: user perception approach. Journal of Transportation Engineering, 134(2), 105109. http://doi.org/10.1061/(ASCE)0733-947X(2008)134:2(105)

Dasgupta, S., \& Tam, E. K. . (2005). Indicators and framework for assessing sustainable infrastructure. Canadian Journal of Civil Engineering, 32, 30-44. http://doi.org/10.1139/104-101

El shenawy, A., \& Zmeureanu, R. (2013). Exergy-based index for assessing the building sustainability. Building and Environment, 60, 202-210. http://doi.org/10.1016/j.buildenv.2012.10.019

Energy star. (2015). Buildings \& Plants. Retrieved November 23, 2015, from https://www.energystar.gov/buildings?s=mega

Environment Canada. (2013). Planning for a Sustainable Future: A Federal Sustainable Development Strategy for Canada 2013-2016. Retrieved from https://www.ec.gc.ca/ddsd/default.asp?lang=en\&n=B8F4119E-1\#fnb6

Federation of Canadian Municipalities. (2002). Developing Levels of Service. Ottawa, ON.

Federation of Canadian Municipalities. (2003). Developing indicators and bechmarks. Ottawa, $\mathrm{ON}$.

Federation of Canadian Municipalities. (2011). Building Canadas Green Economy : The Municipal Role. Ottawa, ON.

Félio, G. Y., \& Lounis, Z. (2009). Model Framework for Assessment of State, Performance, and 
Management of Canada's Core Public Infrastructure. Ottawa, ON. Retrieved from http://www.nrtsi.ca/documents/Framework.E.pdf

Government of British Columbia. (2013). Carbon Neutral Action Reports. Retrieved March 5, 2015, from

http://www2.gov.bc.ca/gov/topic.page?id=BE9BE637F7BA4FFB97AFFE62181F9A67

Green Building Council Denmark. (n.d.). An introduction to DGNB.

Green Building Council of Australia. (2015). List of Credits.

Green Building Initiative. (2014). Green Globes for Existing Buildings Blank Survey.

Grussing, M. N. (2013). Life Cycle Asset Management Methodologies for Buildings. Journal of Infrastructure Systems, (Fhwa 1999), 130404171828002. http://doi.org/10.1061/(ASCE)IS.1943-555X.0000157

Hall, S. (2014). Development and initial trial of a tool to enable improved energy \& human performance in existing commercial buildings. Renewable Energy, 67, 109-118. http://doi.org/10.1016/j.renene.2013.11.022

Han, S., Chae, M. J., Hwang, H., \& Choung, Y. (2015). Evaluation of Customer-Driven Level of Service for Water Infrastructure Asset Management. Journal of Management in Engineering, 31(4). http://doi.org/10.1061/(ASCE)ME.1943-5479.0000293.

Hartkopf, V., \& Loftness, V. (1999). Global relevance of total building performance. Automation in Construction, 8(4), 377-393. http://doi.org/10.1016/S0926-5805(98)00085-5

HKGBC. (2010). BEAM Plus for Existing Buildings. Hong Kong.

Huang, Y.-C., Chu, C.-L., Chang Lee, S.-N., Lan, S.-J., Hsieh, C.-H., \& Hsieh, Y.-P. (2013). Building users' perceptions of importance of indoor environmental quality in long-term care facilities. Building and Environment, 67, 224-230. http://doi.org/10.1016/j.buildenv.2013.05.004

Hyla Environmental Services Ltd. (2011). Corporate energy and GHG emissions plan. Kelowna, BC. Retrieved from http://www.kelowna.ca/CityPage/Docs/PDFs//Environment Division/Climate Change/Corporate Energy and GHG Reduction Plan.pdf

Industry Canada. (2013). Buildings. Retrieved from http://www.ic.gc.ca/eic/site/csrrse.nsf/eng/rs00585.html

Institute for Building Efficiency. (2013). Green Building Rating Systems Japan. Retrieved December 12, 2015, from http://www.institutebe.com/InstituteBE/media/Library/Resources/Green Buildings/FactSheet_Green-Building-Ratings_JAPAN.pdf

Ireland, R., Fearon, P., \& Hawker, L. (2008). Highway Asset Management Quick Start Guidance Note Levels of Service Table of Contents. 2008. London, UK.

Kamali, M., \& Hewage, K. N. (2015). Performance Indicators for Sustainability Assessment of Buildings. In Proceedings of ICSC15: The Canadian Society for Civil Engineering 5th International/11th Construction Specialty Conference (pp. 1-11). Vancouver, BC: 
Canadian Society of Civil Engineers.

Khan, Z., Moselhi, O., \& Zayed, T. (2009). Keywords: Analytical Hierarchy Process, Asset Management, Level of Service, Performance Indicator. In Pipelines 2009 (pp. 1463-1472). ASCE. http://doi.org/10.1061/41069(360)139

Khan, Z., Moselhi, O., \& Zayed, T. (2014). Identifying Rehabilitation Options for Optimum Improvement in Municipal Asset Condition. Journal of Infrastructure Systems, 21(2), 4014037. http://doi.org/10.1061/(ASCE)IS.1943-555X.0000220.

Khatri, K. B., Vairavamoorthy, K., \& Akinyemi, E. (2011). Framework for Computing a Performance Index for Urban Infrastructure Systems Using a Fuzzy Set Approach. Journal of Infrastructure Systems, 17(December), 163-175. http://doi.org/10.1061/(ASCE)IS.1943555X.0000062.

Lai, J. H. K., \& Man, C. S. (2017). Developing a performance evaluation scheme for engineering facilities in commercial buildings: state-of-the-art review. International Journal of Strategic Property Management, 21(1). http://doi.org/10.3846/1648715X.2016.1247304

Lai, J. H. K., \& Yik, F. W. H. (2009). Perception of importance and performance of the indoor environmental quality of high-rise residential buildings. Building and Environment, 44(2), 352-360. http://doi.org/10.1016/j.buildenv.2008.03.013

Lavy, S., Garcia, J. A., Scinto, P., \& Dixit, M. K. (2014a). Key performance indicators for facility performance assessment: simulation of core indicators. Construction Management and Economics, 32(12), 1183-1204. http://doi.org/10.1080/01446193.2014.970208

Lavy, S., Garcia, J. A., Scinto, P., \& Dixit, M. K. (2014b). Key performance indicators for facility performance assessment: simulation of core indicators. Construction Management and Economics, 32(12), 1183-1204. http://doi.org/10.1080/01446193.2014.970208

Lawrence, R., \& Keime, C. (2016). Bridging the gap between energy and comfort: Postoccupancy evaluation of two higher-education buildings in Sheffield. Energy and Buildings, 130, 651-666. http://doi.org/10.1016/j.enbuild.2016.09.001

Leaman, A., \& Bordass, B. (2001). Assessing building performance in use 4: the Probe occupant surveys and their implications. Building Research \& Information, 29(2), 129-143. http://doi.org/10.1080/09613210010008045

Lepkova, N., \& Ūselis, R. (2013). Development of a Quality Criteria System for Facilities Management Services in Lithuania. Procedia Engineering, 57, 697-706. http://doi.org/10.1016/j.proeng.2013.04.088

Lin, J., \& Young, D. (2009). Energy Efficiency in Canadian Commercial Buildings : Evidence from 2000 and 2005. Edmonton, $\mathrm{AB}$.

Mahbub, A. S., Kua, H.-W., \& Lee, S.-E. (2010). A total building performance approach to evaluating building acoustics performance. Architectural Science Review, 53(2), 213-223. http://doi.org/10.3763/asre.2009.0032

Mirza, S. (2007). The Comming Collapse of Canadas Municipal Infrastructure. Ottawa ON: Federation of Canadian Municipalities. 
Mistry, V. (2007). Briefing: BREEAM —-making what is important measurable. Proceedings of the ICE - Engineering Sustainability, 160(March), 11-14.

http://doi.org/10.1680/ensu.2007.160.1.11

Namini, S. B., Preece, C., Tahmasebi, M. M., \& Shakouri, M. (2014). Managerial sustainability assessment tool for Iran's buildings. Proceedings of the ICE - Engineering Sustainability, 167(1), 12-23. http://doi.org/10.1680/ensu.12.00041

National Institute of Building Sciences. (2012). Cost-Effective. Retrieved August 15, 2016, from https://www.wbdg.org/design/cost_effective.php

National Institute of Building Sciences. (2015). Secure / Safe. Retrieved August 15, 2016, from https://www.wbdg.org/design/secure_safe.php

Ng, S. T., Chen, Y., \& Wong James M.W., J. M. W. (2013). Variability of building environmental assessment tools on evaluating carbon emissions. Environmental Impact Assessment Review, 38, 131-141. http://doi.org/10.1016/j.eiar.2012.07.003

Nguyen, B. K., \& Altan, H. (2011). Comparative Review of Five Sustainable Rating Systems. Procedia Engineering, 21(0), 376-386. http://doi.org/10.1016/j.proeng.2011.11.2029

Nilashi, M., Zakaria, R., Ibrahim, O., Majid, M. Z. A., Mohamad Zin, R., Chugtai, M. W., ... Aminu Yakubu, D. (2015). A knowledge-based expert system for assessing the performance level of green buildings. Knowledge-Based Systems, 86, 194-209. http://doi.org/10.1016/j.knosys.2015.06.009

Office of Government Commerce. (2007). Service transition. Norwich: The stationary office.

Oyedele, L. O., Tham, K. W., Fadeyi, M. O., \& Jaiyeoba, B. E. (2012). Total Building Performance Approach in Building Evaluation : Case Study of an Office Building in Singapore. Journal of Energy Engineering, 138(March), 25-30. http://doi.org/10.1061/(ASCE)EY.1943-7897.0000056.

Parasuraman, A., Zeithaml, V. A., \& Berry, L. L. (2016). A Conceptual Model of Service Quality and Its Implications for Future Research. Journal of Marketing, 49(4), 41-50.

Parrat, J., Donzé, G., Iseli, C., Perret, D., Tomicic, C., \& Schenk, O. (2012). Assessment of occupational and public exposure to trichloramine in Swiss indoor swimming pools: a proposal for an occupational exposure limit. Annals of Occupational Hygiene, 56(3), 264277.

Rajani, B. B., Kleiner, Y., \& Sadiq, R. (2006). Translation of pipe inspection results into condition rating using fuzzy synthetic valuation technique. Journal of Water Supply Research and Technology: Aqua, 55(1), 11-24.

Rincón, L., Castell, A., Pérez, G., Solé, C., Boer, D., \& Cabeza, L. F. (2013). Evaluation of the environmental impact of experimental buildings with different constructive systems using Material Flow Analysis and Life Cycle Assessment. Applied Energy, 109, 544-552. http://doi.org/10.1016/j.apenergy.2013.02.038

Ross, T. J. (2005). Fuzzy logic with engineering applications. Hoboken, N.J: John Wiley \& Sons. 
Ruparathna, R., Hewage, K., \& Sadiq, R. (2015). Assessment of the level of service (LOS) of public recreational centre buildings : an uncertainty based approach. In 5th International Construction Specialty Conference of the Canadian Society for Civil Engineering (ICSC) (pp. 1-10). Vancouver, BC: Canadian Society of Civil Engineers.

Ruparathna, R., Hewage, K., \& Sadiq, R. (2016). Improving the energy efficiency of the existing building stock: A critical review of commercial and institutional buildings. Renewable and Sustainable Energy Reviews, 53, 1032-1045. http://doi.org/10.1016/j.rser.2015.09.084

Sadiq, R., Al-Zahranib, M. A., Sheikhc, A. K., Husaind, T., \& Farooq, S. (2004). Performance evaluation of slow sand filters using fuzzy rule-based modelling. Environmental Modelling \& Software, 19(5), 507-515. http://doi.org/10.1016/S1364-8152(03)00165-8

Sadiq, R., Husain, T., Veitch, B., \& Bose, N. (2004). Risk-based decision-making for drilling waste discharges using a fuzzy synthetic evaluation technique. Ocean Engineering, 31(16), 1929-1953. http://doi.org/10.1016/j.oceaneng.2004.05.001

Sadiq, R., \& Rodriguez, M. J. (2004). Fuzzy synthetic evaluation of disinfection by-products-a risk-based indexing system. Journal of Environmental Management, 73(1), 1-13. http://doi.org/10.1016/j.jenvman.2004.04.014

Sharma, V., Al-hussein, M., Asce, M., Safouhi, H., \& Bouferguène, A. (2008). Municipal Infrastructure Asset Levels of Service Assessment, (September), 193-200.

Sharma, V., Al-Hussein, M., Safouhi, H., \& Bouferguène, A. (2008). Municipal Infrastructure Asset Levels of Service Assessment for Investment Decisions Using Analytic Hierarchy Process. Journal of Infrastructure Systems, 14(3), 193-200. http://doi.org/10.1061/(ASCE)1076-0342(2008)14:3(193)

Shohet, I. M. (2003). Building evaluation methodology for setting maintenance priorities in hospital buildings. Construction Management and Economics, 21(7), 681-692. http://doi.org/10.1080/0144619032000115562

Shoolestani, A., Shoolestani, B., Froese, T., \& Vanier, D. J. (2015a). SocioBIM : BIM-to-end user interaction for sustainable building operations and facility asset management. 5th International/11 th Construction Specialty Conference, (2014), 3261-3266. http://doi.org/DOI: 10.14288/1.0076332

Shoolestani, A., Shoolestani, B., Froese, T., \& Vanier, D. J. (2015b). SocioBIM : BIM-to-end user interaction for sustainable building operations and facility asset management. 5th International/11th Construction Specialty Conference, (2014), 3261-3266. http://doi.org/DOI: 10.14288/1.0076332

Siu, G. K. W., Bridge, A., \& Skitmore, M. (2001). Assessing the service quality of building maintenance providers : mechanical and engineering services. Construction Management and Economics, 19(7), 719-726. http://doi.org/10.1080/01446190110062104

Srinivasan, R. S., Ingwersen, W., Trucco, C., Ries, R., \& Campbell, D. (2014). Comparison of energy-based indicators used in life cycle assessment tools for buildings. Building and Environment, 79, 138-151. http://doi.org/10.1016/j.buildenv.2014.05.006

Støre-Valen, M., \& Lohne, J. (2016). Analysis of assessment methodologies suitable for building 
performance. Facilities, 34(13/14), 726-747. http://doi.org/10.1108/F-12-2014-0103

Transportation Research Board. (2006). COOPERATIVE HIGHWAY PROGRAM. Washington, DC: Transportation research board.

Transportation Research Board. (2013). Transit Capacity and Quality of Service Manual. Washington, DC: Transportation research board.

U.S. General Services Administration. (2016). Lighting. Retrieved January 2, 2017, from https://www.gsa.gov/portal/content/101308

Umer, A., Hewage, K., Haider, H., \& Sadiq, R. (2016). Sustainability assessment of roadway projects under uncertainty using Green Proforma: An index-based approach. International Journal of Sustainable Built Environment. http://doi.org/10.1016/j.ijsbe.2016.06.002

United Nations. (2004). Accessibility for the Disabled - A Design Manual for a Barrier Free Environment. Retrieved January 17, 2017, from http://www.un.org/esa/socdev/enable/designm/AD3-01.htm

United States Environmental Protection Agency (USEPA). (2012). Asset Management. Retrieved June 15, 2015, from http://water.epa.gov/infrastructure/sustain/asset_management.cfm

USEPA. (2010). Fundamentals of Asset Management. Retrieved December 1, 2016, from https://www.epa.gov/sites/production/files/2016-01/documents/set-target-level-ofservice.pdf

Vijayan, A., \& Kumar, A. (2005). Development of a tool for analyzing the sustainability of residential buildings in Ohio. Environmental Progress, 24(3), 238-247. http://doi.org/10.1002/ep.10095

Vučićević, B., Jovanović, M., Afgan, N., \& Turanjanin, V. (2014). Assessing the sustainability of the energy use of residential buildings in Belgrade through multi-criteria analysis. Energy and Buildings, 69, 51-61. http://doi.org/10.1016/j.enbuild.2013.10.022

Waggett, R., \& Arotsky, C. (2006). Water Key Performance Indicators and benchmarks for offices and hotels. CIRIA Publications, C657, 1-14.

Wang, S., Yan, C., \& Xiao, F. (2012). Quantitative energy performance assessment methods for existing buildings. Energy and Buildings, 55, 873-888. http://doi.org/10.1016/j.enbuild.2012.08.037

Warnock, A. C. C. (2001). Specifying Acoustical Criteria for Buildings. Construction Technology Update, (50). Retrieved from http://www.nrc-cnrc.gc.ca/ctu-sc/files/doc/ctusc/ctu-n50_eng.pdf

Wong, N. H., \& Jan, W. L. S. (2003). Total building performance evaluation of academic institution in Singapore. Building and Environment, 38(1), 161-176. http://doi.org/10.1016/S0360-1323(02)00021-5

Zadeh, L. (1965). Fuzzy sets. Information and Control, 353, 338-353.

Zhao, J., Xin, Y., \& Tong, D. (2012). Energy consumption quota of public buildings based on 
statistical analysis. Energy Policy, 43, 362-370. http://doi.org/10.1016/j.enpol.2012.01.015

Zhao, L., Bian, Y., Rong, J., Liu, X., \& Shu, S. (2016). Evaluation method for pedestrian level of service on sidewalks based on fuzzy neural network model. Journal of Intelligent \& Fuzzy Systems, 30(5), 2905-2913. http://doi.org/10.3233/IFS-151753

Zimmermann, H. J. (2010). Fuzzy set theory. Wiley Interdisciplinary Reviews: Computational Statistics, 2, 317-332. http://doi.org/10.1002/wics.82

Zimring, C. (2014). Facility Performance Evaluation (FPE). Retrieved January 11, 2016, from https://www.wbdg.org/resources/fpe.php?r=utilize_management 


\section{Appendices}

\section{Appendix A: Level of service indicators for buildings}

\section{Indicator}

I1 Availability of measures for protection against vandalism and security

I2 User satisfaction level (Through a survey)

I3 Indoor air quality (IAQ)

I Thermal comfort to the users

I5 Building cleanliness and visual comfort to the users

I6 Indoor noise level

I7 Indoor luminance level

I8 Adequacy of building amenities to users (Customizable based on the building type)

I9 Condition rating of building equipment

I10 Access to services in normal and emergency conditions

I11 Number of deaths, injuries and illnesses while using assets or services

I12 Non planned service interruptions as a percentage to planned service interruptions

I13 Number of user days with no service interruptions

I14 Quality of swimming pool water

I15 Annual energy use intensity $\left(\mathrm{GJ} / \mathrm{m}^{2}\right)$

I16 Annual renewable energy consumption (As a proportion of the total energy)

\section{Reference}

(Félio \& Lounis, 2009)

(Green Building Council of Australia, 2015)

(Namini et al., 2014)(HKGBC, 2010)(Canada Green Building Council, 2009a)(Green Building Council of Australia, 2015) (Green Building Council Denmark, n.d.)(Institute for Building Efficiency, 2013)(Green Building Initiative, 2014) (Canada Green Building Council, 2009a)(Canada Green Building Council, 2009a)(Institute for Building Efficiency, 2013) (Lai \& Yik, 2009)

(HKGBC, 2010)(Green Building Council of Australia, 2015)(Green Building Council Denmark, n.d.)(Lai \& Yik, 2009)(Atzeri, Cappelletti, Tzempelikos, \& Gasparella, 2016)

(Canada Green Building Council, 2009a)(Green Building Council of Australia, 2015)(Institute for Building Efficiency, 2013)(Institute for Building Efficiency, 2013)(Green Building Initiative, 2014) (Green Building Council Denmark, n.d.)

(Oyedele et al., 2012)(HKGBC, 2010) (Kamali \& Hewage, 2015) (Green Building Council of Australia, 2015)(Lai \& Yik, 2009)

(Namini et al., 2014) (Canada Green Building Council, 2009a)(Green Building Council of Australia, 2015)(Institute for Building Efficiency, 2013)(Institute for Building Efficiency, 2013)(Green Building Initiative, 2014)

(Correia \& Wirasinghe, 2008)

(Green Building Council Denmark, n.d.) (Félio \& Lounis, 2009) (Institute for Building Efficiency, 2013)(Green Building Initiative, 2014)

(Félio \& Lounis, 2009)

(Félio \& Lounis, 2009)

(Félio \& Lounis, 2009)(Han et al., 2015)

(Félio \& Lounis, 2009)(Han et al., 2015)

(Green Building Initiative, 2014)

(Vijayan \& Kumar, 2005)(Vučićević et al., 2014)(Srinivasan, Ingwersen, Trucco, Ries, \& Campbell, 2014)(El shenawy \& Zmeureanu, 2013) (HKGBC, 2010)(BRE Global, 2012)(Green Building Council Denmark, n.d.) (Energy star, 2015)(Institute for Building Efficiency, 2013)(Augenbroe, Castro, \& Ramkrishnan, 2009)

(Namini et al., 2014) (HKGBC, 2010)(Canada Green Building Council, 2009a)(Green Building Council Denmark, n.d.)(Institute for Building Efficiency, 2013)(Green Building Initiative, 2014) 
I17 Annual GHG emission reduction

I18 Annual water consumption per user

I19 Amount of water recycled as a \% to waste water

I20 Average cost of operation as a percentage of annual income

I 21 Amenities for persons with disability

I22 Cycling convenience for the users
(Vučićević et al., 2014)(El shenawy \& Zmeureanu, 2013) (HKGBC, 2010)(BRE Global, 2012)(Green Building Council of Australia, 2015)(Green Building Council Denmark, n.d.)(Institute for Building Efficiency, 2013)

(Vijayan \& Kumar, 2005)(El shenawy \& Zmeureanu, 2013) (HKGBC, 2010)(BRE Global, 2012)(Green Building Council Denmark, n.d.)

(HKGBC, 2010)(Green Building Council of Australia, 2015) (Institute for Building Efficiency, 2013)

(Green Building Council of Australia, 2015)

(Namini et al., 2014)(HKGBC, 2010)

(Green Building Council Denmark, n.d.) 
Appendix B: Indicator benchmarks

\section{Performance levels}

\begin{tabular}{|c|c|c|c|c|c|c|c|}
\hline 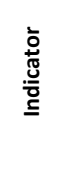 & 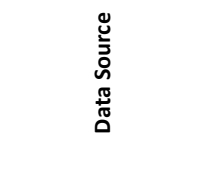 & 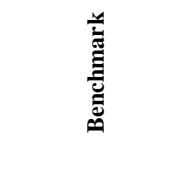 & 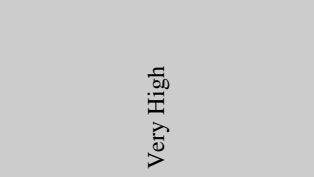 & $\stackrel{50}{.00}$ & $\begin{array}{l}\frac{0}{\pi} \\
\frac{\pi}{0} \\
\sum\end{array}$ & 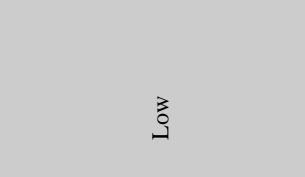 & $\begin{array}{l}\frac{3}{0} \\
\frac{1}{3} \\
>0 \\
0\end{array}$ \\
\hline $\mathbf{I}_{1}$ & $\begin{array}{l}\text { Qualitative / } \\
\text { Observation }\end{array}$ & $\begin{array}{l}\text { Municipality } \\
\text { defined }\end{array}$ & $\begin{array}{l}\text { State of the art security } \\
\text { features are installed (e.g. } \\
\text { sensors), building is } \\
\text { continuously monitored and } \\
\text { security service is stationed at } \\
\text { the facility }\end{array}$ & $\begin{array}{l}\text { building is continuously } \\
\text { monitored and security service } \\
\text { conducts routine patrols }\end{array}$ & $\begin{array}{l}\text { Security service is contracted } \\
\text { and they conduct routine } \\
\text { patrols }\end{array}$ & $\begin{array}{l}\text { Building is monitored using } \\
\text { CCTV }\end{array}$ & $\begin{array}{l}\text { No security measures are in } \\
\text { place }\end{array}$ \\
\hline $\mathbf{I}_{2}$ & Through a survey & $\begin{array}{l}\text { Municipality } \\
\text { defined }\end{array}$ & Very Satisfied & Satisfied & Neutral & Dissatisfied & Very Dissatisfied \\
\hline $\mathbf{I}_{3}$ & Measured $\left(\mathrm{mg} / \mathrm{m}^{3}\right)$ & $\begin{array}{l}\text { Literature (Parrat } \\
\quad \text { et al., 2012) }\end{array}$ & & & $0.2-0.3$ & $0.3<$ & \\
\hline $\mathbf{I}_{4}$ & Measured $\left({ }^{\circ} \mathrm{C}\right)$ & $\begin{array}{l}\text { Municipality } \\
\text { defined }\end{array}$ & $25-26$ & & $22-24$ & & $<22 \&>26$ \\
\hline $\mathbf{I}_{5}$ & Through a survey & $\begin{array}{l}\text { Municipality } \\
\text { defined }\end{array}$ & Excellent & Good & Moderate & $\mathrm{Bad}$ & Very bad \\
\hline $\mathbf{I}_{6}$ & Measured $(\mathrm{dB}(\mathrm{A})$ ) & $\begin{array}{l}\text { NRC (Warnock, } \\
\text { 2001) }\end{array}$ & & & $40-45$ & & $45<$ \\
\hline $\mathbf{I}_{7}$ & $\begin{array}{l}\text { Measured } \\
\text { (Lumens/Square } \\
\text { Meter) }\end{array}$ & $\begin{array}{l}\text { U.S. General } \\
\text { Services } \\
\text { Administration } \\
\text { (U.S. General } \\
\text { Services } \\
\text { Administration, } \\
\text { 2016) }\end{array}$ & & & $500-750$ & & $00>$ \\
\hline $\mathbf{I}_{8}$ & Through a survey & $\begin{array}{l}\text { Municipality } \\
\text { defined }\end{array}$ & Very Satisfied & Satisfied & Neutral & Dissatisfied & Very Dissatisfied \\
\hline $\mathbf{I}_{9}$ & Expert judgement & $\begin{array}{l}\text { Municipality } \\
\text { defined }\end{array}$ & Excellent & Good & Fair & About to fail & Failed \\
\hline $\mathbf{I}_{10}$ & Expert judgement & $\begin{array}{c}\text { Canadian Centre } \\
\text { for Occupational } \\
\text { Health \& Safety, } \\
\text { Emergency } \\
\text { Planning } \\
\text { (Canadian Centre } \\
\text { for Occupational } \\
\text { Health \& Safety, } \\
\text { 2017) }\end{array}$ & $\begin{array}{l}\text { Emergency preparedness plan } \\
\text { is established updated and } \\
\text { regular drills are conducted }\end{array}$ & $\begin{array}{l}\text { Emergency preparedness plan } \\
\text { is established and regular } \\
\text { drills are conducted }\end{array}$ & $\begin{array}{l}\text { Emergency preparedness plan } \\
\text { is available }\end{array}$ & $\begin{array}{l}\text { Standard safety and } \\
\text { emergency plans are } \\
\text { available }\end{array}$ & $\begin{array}{l}\text { No emergency response } \\
\text { procedures }\end{array}$ \\
\hline $\mathbf{I}_{11}$ & Daily logs & $\begin{array}{l}\text { Municipality } \\
\text { defined }\end{array}$ & $0-2$ & $1-3$ & $2-4$ & 3-5 & $5<$ \\
\hline $\mathbf{I}_{12}$ & $\begin{array}{l}\text { Daily logs } \\
\text { (Percentage) }\end{array}$ & $\begin{array}{c}\text { Municipality } \\
\text { defined }\end{array}$ & $0-2 \%$ & $1-3 \%$ & $2-4 \%$ & $3-5 \%$ & $5 \%<$ \\
\hline
\end{tabular}




\begin{tabular}{|c|c|c|c|c|c|c|c|}
\hline $\mathbf{I}_{13}$ & Daily logs & $\begin{array}{l}\text { Municipality } \\
\text { defined }\end{array}$ & $0-2$ & $1-3$ & $2-4$ & $3-5$ & $5<$ \\
\hline$I_{14}$ & $\begin{array}{l}\text { Monitored } \\
\text { information }\end{array}$ & $\begin{array}{l}\text { BC Ministry of } \\
\text { Health (BC } \\
\text { Ministry of } \\
\text { Health, 2014) }\end{array}$ & $\begin{array}{l}\text { Chemical parameters are } \\
\text { maintained in the specified } \\
\text { range and no health concerns } \\
\text { are reported }\end{array}$ & $\begin{array}{l}\text { Chemical characteristics of } \\
\text { pool waster is maintained } \\
\text { between following ranges; } \\
\text { free chlorine } 0.5-5 \mathrm{ppm} ; \\
\text { chlorine cyanurate } 1-5 \mathrm{ppm} ; \\
\text { bromine } 1.5-5 \mathrm{ppm} \text {; combined } \\
\text { chlorine <1ppm; } \mathrm{pH} 7.2-7.8 \text {; } \\
\text { total alkalinity } 80-120 ; \\
\text { calcium hardness } 180-220 \text {; }\end{array}$ & $\begin{array}{l}\text { Chemical parameters slightly } \\
\text { deviate from the specified } \\
\text { range }\end{array}$ & $\begin{array}{l}\text { Chemical parameters } \\
\text { significantly deviate from the } \\
\text { specified range }\end{array}$ & $\begin{array}{l}\text { Chemical parameters } \\
\text { significantly deviate from the } \\
\text { specified range and health } \\
\text { problems are reported }\end{array}$ \\
\hline$I_{15}$ & $\begin{array}{c}\text { Monitored } \\
\text { information }\left(\mathrm{GJ} / \mathrm{m}^{2}\right)\end{array}$ & $\begin{array}{l}\text { CIBSE(CIBSE, } \\
\text { 2001) }\end{array}$ & $<725$ & $725-1573$ & 1149-1997 & 1573-1997 & 1785 \\
\hline$I_{16}$ & $\begin{array}{l}\text { Monitored } \\
\text { information (As } \\
\text { proportion of total } \\
\text { energy) }\end{array}$ & $\begin{array}{l}\text { LEED (Canada } \\
\text { Green Building } \\
\text { Council, 2009b) }\end{array}$ & $>12 \%$ & $12-7.5 \%$ & $9-6 \%$ & $6-3$ & $3 \%>$ \\
\hline $\mathbf{I}_{17}$ & $\begin{array}{l}\text { Calculated using } \\
\text { energy demand } \\
\text { (Percentage of GHG } \\
\text { emission reduction } \\
\text { from the previous } \\
\text { year) }\end{array}$ & $\begin{array}{l}\text { Municipality } \\
\text { defined based on } \\
\text { climate action } \\
\text { plans }\end{array}$ & $>33 \%$ & $33 \%-20 \%$ & $20 \%-0$ & 0 & Increase \\
\hline $\mathbf{I}_{18}$ & $\begin{array}{l}\text { Monitored } \\
\text { information } \\
\left(\mathrm{m}^{3} / \mathrm{user} / \mathrm{annum}\right)\end{array}$ & $\begin{array}{l}\text { CIRIA (Waggett } \\
\& \text { Arotsky, 2006) }\end{array}$ & $<60$ & $60-130$ & $95-175$ & $130-220$ & $220<$ \\
\hline $\mathbf{I}_{19}$ & $\begin{array}{c}\text { Monitored } \\
\text { information } \\
\text { (Percentage of waste } \\
\text { water recycled) }\end{array}$ & $\begin{array}{l}\text { LEED (Canada } \\
\text { Green Building } \\
\text { Council, 2009b) }\end{array}$ & $<1 \%$ & $1-2 \%$ & $1-3 \%$ & $2-4 \%$ & $4 \%<$ \\
\hline $\mathbf{I}_{20}$ & $\begin{array}{c}\text { Calculated data from } \\
\text { P\&L }\end{array}$ & $\begin{array}{l}\text { Municipality } \\
\text { defined }\end{array}$ & & & 0 & & $0<$ \\
\hline $\mathbf{I}_{21}$ & $\begin{array}{l}\text { Monitored } \\
\text { information }\end{array}$ & $\begin{array}{l}\text { United Nations } \\
\text { (United Nations, } \\
\text { 2004) }\end{array}$ & $\begin{array}{l}\text { Standard facilities are } \\
\text { available for disabled workers } \\
\text { and visitors. Multiple } \\
\text { entrances one shower room, } \\
\text { one rest room and one } \\
\text { changing room per facility } \\
\text { should be accessible to a } \\
\text { wheelchair user. Sports halls } \\
\text { and spectator areas are } \\
\text { accessible. }\end{array}$ & $\begin{array}{l}\text { Standard facilities are } \\
\text { available for disabled workers } \\
\text { and visitors. Multiple } \\
\text { entrances are available. }\end{array}$ & $\begin{array}{c}\text { Standard amenities are } \\
\text { available disabled workers } \\
\text { and visitors. Entrance via } \\
\text { main entrance }\end{array}$ & $\begin{array}{l}\text { Building can be accessed by } \\
\text { a wheel chair user via } \\
\text { alternative entrance }\end{array}$ & $\begin{array}{l}\text { Limited amenities are available } \\
\text { for disabled. }\end{array}$ \\
\hline$I_{22}$ & $\begin{array}{l}\text { Monitored } \\
\text { information }\end{array}$ & $\begin{array}{l}\text { City of Nelson } \\
\text { (City of Nelson, } \\
\text { 2013) }\end{array}$ & $\begin{array}{l}\text { Bicycle parking lockers are } \\
\text { available for within } 15 \mathrm{~m} \text { of } \\
\text { the entrance. Bicycle parking } \\
\text { is well lit, visible to visitors } \\
\text { and separated from car } \\
\text { parking }\end{array}$ & $\begin{array}{l}\text { Bicycle parking is within } 15 \mathrm{~m} \\
\text { to the main entrance and } \\
\text { separated from car parking. }\end{array}$ & $\begin{array}{l}\text { Bicycle parking is available in } \\
\text { a side of the building and is } \\
\text { separated from car parking. }\end{array}$ & $\begin{array}{l}\text { Bicycle parking is not } \\
\text { separated from car parking } \\
\text { available at a side of the } \\
\text { building. }\end{array}$ & No parking facilities for cyclists \\
\hline
\end{tabular}

